Cuadernos de Historia Contemporánea

ISSN: 0214-400X

http://dx.doi.org/10.5209/CHCO.56270

\title{
Retratos des-compuestos: cinco peculiares caricaturas del Sexenio democrático
}

\author{
Blanca Redondo González ${ }^{1}$
}

Recibido: 30 de marzo de 2017 / Aceptado: 22 de mayo de 2017

Resumen. Durante el Sexenio democrático fueron publicadas en los semanarios satíricos $E l$ Caos y El Lío cinco caricaturas que recuerdan, al menos formalmente, a las cabezas compuestas que pintase en el siglo XVI Giuseppe Arcimboldo. En el presente artículo se estudian las circunstancias en las que aparecieron los cinco dibujos y se comparan con las pinturas del artista del Cinquecento a través de la lectura que de las cabezas compuestas originales hiciese el filósofo Roland Barthes. El objetivo que subyace en este ejercicio de equiparación es el análisis del procedimiento y de los recursos de los que pudieron valerse los dos autores de las caricaturas.

Palabras clave: Giuseppe Arcimboldo; Eduardo Sojo; Tomás Padró; Sexenio democrático; prensa y público; caricatura; tropo; iconografía.

\section{De-composite Portraits: Five Peculiar Caricatures of the Democratic Six-Years}

\begin{abstract}
During the democratic Six-Years, five caricatures were published in the satirical weekly journals El Caos and El Lio that resemble, at least formally, the composite heads painted in the sixteenth century by Giuseppe Arcimboldo. This article examines the circumstances in which the five drawings appeared and are compared with the paintings of the Cinquecento artist through the study of the original composite heads made by the philosopher Roland Barthes. The objective underlying this exercise of equalization is the analysis of the process and the resources that could be used by the two authors of the cartoons.
\end{abstract}

Keywords: Giuseppe Arcimboldo; the democratic Six-Years; press and audience; caricature; satire; trope; iconography.

Sumario. Introducción. 1. España bien vale una caricatura. 2. Publicaciones para su público. 3. La importancia de llamarse "artista". 4. ¿Inspiración directa o indirecta? 5. Otro laboratorio de tropos. 6. Vicios cardinales. 7. Juegos de la deformación. 8. Referencias bibliográficas*.

Cómo citar: Redondo González, B. (2017). "Retratos des-compuestos: cinco peculiares caricaturas del Sexenio democrático". Cuadernos de Historia Contemporánea, 39, 155-190.

1 Universidad Complutense de Madrid (España)

E-mail: brgonzalez@ucm.es

* En varias ocasiones recurrimos a prensa publicada entre 1869 y 1875 ; la gran mayoría de nuestros ejemplos carecen de firma y algunos tampoco tienen título. No obstante, señalamos la localización del texto. Al redactar las referencias bibliográficas hemos optado por agruparlos a todos al final, por orden alfabético de la publicación. 


\section{Introducción}

A la manera de las "cabezas compuestas" que ideara y pintase el milanés Giuseppe Arcimboldo, aparecieron, en la segunda mitad del siglo XIX, cinco caricaturas en dos semanarios satíricos españoles. Las primeras en publicarse, en el verano de 1870, fueron las del periódico madrileño El Caos: dos punzantes retratos de Juan Moreno Benítez (figura 1), Gobernador Civil de Madrid tras la revolución de 1868, y de Antonio de Orleans (figura 2), duque de Montpensier, marido de Luisa Fernanda -quien era la hermana de Isabel II- y pretendiente al trono de España, durante algún tiempo. Cuatro años después, El Lio, editado en Barcelona, sacaba las otras tres caricaturas: la de Francisco Savalls (figura 3), cabecilla carlista en la zona de Barcelona, la de Antonio de Orleans (figura 4) -otra vez, pues era uno de los personajes favoritos de los caricaturistas- y, por último, la de Carlos María de Borbón (figura 5): el rey tan vehementemente propuesto por los carlistas. Los dibujos de El Lio fueron realizados por Tomás Padró, dibujante único de la publicación, y los de El Caos, por Eduardo Sojo, el director del periódico, que más tarde adoptaría el pseudónimo de Demócrito².

Satirizaban contra cuatro personajes de la esfera pública española a través de las páginas de dos de los múltiples semanarios satíricos que salieron a la luz a raíz de una serie de desatinados acontecimientos políticos.

Si grande e impetuosa fue, al menos por el número, la irrupción de periódicos diarios que subsiguió a la Revolución, todavía lo fue más la de las publicaciones, generalmente semanales, llamadas "satíricas", porque, por lo común, el ingenio español muestra una inclinación mayor a combatir, sea a quien sea, con las armas del sarcasmo y del ridículo que con las del razonamiento ${ }^{3}$.

Aunque el autor de la cita justifica dicha irrupción con la inclinación hacia el uso indiscriminado del sarcasmo y del ridículo, en vez de valerse del razonamiento, veremos algunos motivos que pudieron tener los autores para ser sarcásticos, cosa que, por cierto, sí implica reflexión: «La distorsión de lo serio [...] permitirá arrojar luz sobre aspectos de otra manera desapercibidos $\rangle^{4}$.

Se pretende a continuación exponer un acercamiento a un inusual grupo de caricaturas que fueron creadas por dos artistas bajo unas circunstancias concretas que pueden dar cuenta del porqué de tan particulares láminas. El estudio de estas caricaturas ha implicado ahondar en los personajes retratados a través de los símbolos que los componen; si bien las caricaturas, en general, han sido reutilizadas posteriormente para ilustrar libros de historia, en el transcurso de esta investigación ha ocurrido lo contrario: a través del dibujo hemos conocido la historia. Ha sucedido de este modo

2 Esto ocurriría tras la Restauración borbónica. Véase Laguna Platero, Antonio y Martínez Gallego, Francesc Andreu: "Eduardo Sojo, el Quijote de la caricatura" [en línea], en IC-Revista Científica de Información y Comunicación, 12 (2015), p. 118. [Consulta: 28 de diciembre de 2016]. Disponible en: https://idus.us.es/xmlui/ handle/11441/33051.

3 Gómez Aparicio, Pedro: Historia del periodismo español. De la Revolución de Septiembre al desastre colonial, Madrid, Editora Nacional, 1971, p. 60.

4 Bozal, Valeriano: "El grabado popular en el siglo XIX", en Juan Carrete, Jesusa Vega, Valeriano Bozal y Francesc Fontbona: El grabado en España. Siglos XIX y XX, Madrid, Espasa Calpe, 1988, vol. XXXII de Summa Artis, p. 320. 
gracias a que hemos leído las imágenes de manera análoga a como lo hiciera Roland Barthes con las cabezas compuestas de Giuseppe Arcimboldo. Es este proceso de lectura en el que más nos detendremos, para además hallar coincidencias y discrepancias con el modelo que pudo suponer el pintor milanés.

Figura 1. Eduardo Sojo: [Sin título], El Caos, 11 (13 de junio de 1870).

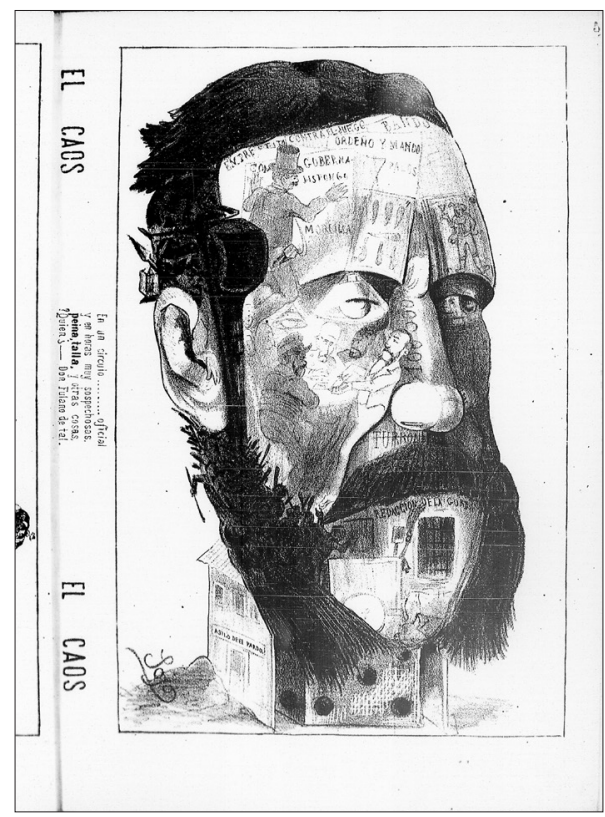

Figura 2. Eduardo Sojo: «LA CABEZA CONSPIRANTE», El Caos, 14 (4 de julio de 1870).

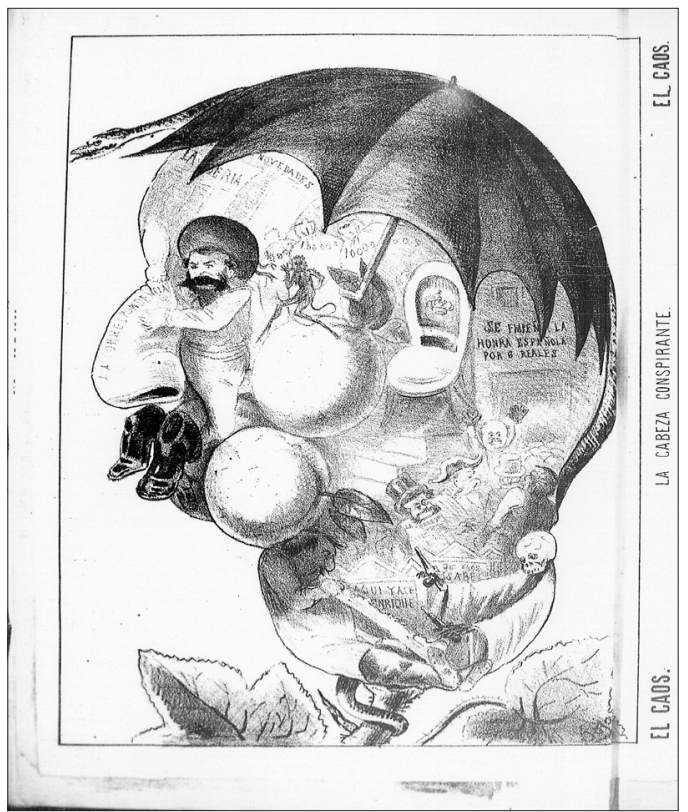


Figura 3. $\mathrm{A}^{\circ} \mathrm{W}^{\mathrm{o}}$ (Tomás Padró): «RETRATOS ALEGÓRICOS. SAVALLS», El Lio, 1 (7 de febrero de 1874).

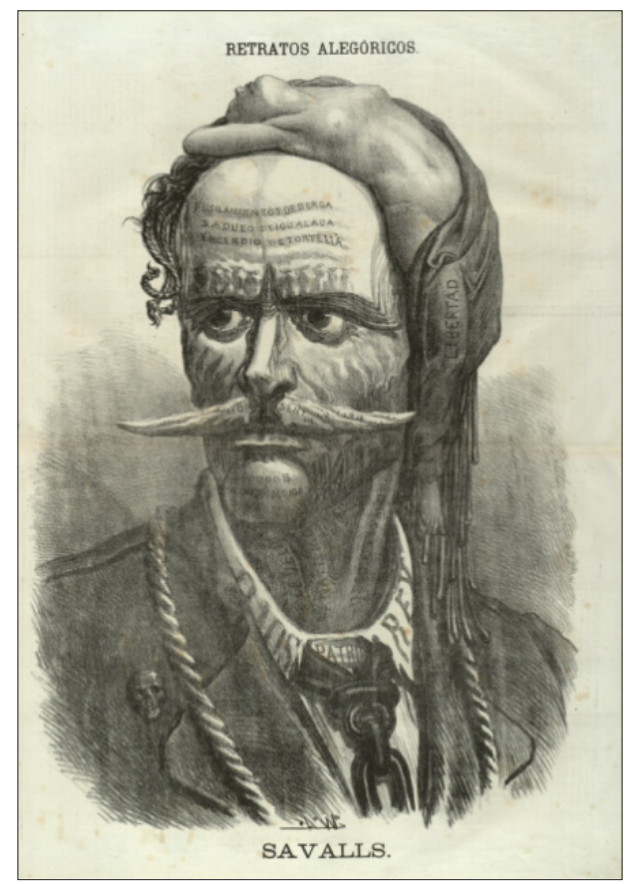

Figura 4. $\mathrm{A}^{\circ} \mathrm{W}^{\mathrm{o}}$ (Tomás Padró): «RETRATOS ALEGÓRICOS. EL NARANJERO», El Lio, 4 (7 de marzo de 1874).

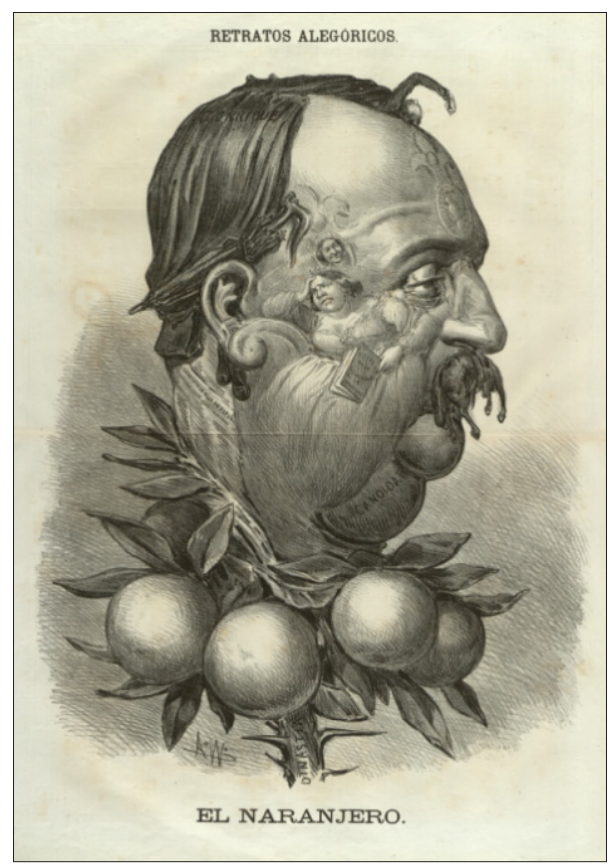


Figura 5. $\mathrm{A}^{\mathrm{o}} \mathrm{W}^{\mathrm{o}}$ (Tomás Padró): «RETRATOS ALEGÓRICOS. S. M. TERSA», El Lio 7 (18 de junio de 1874).

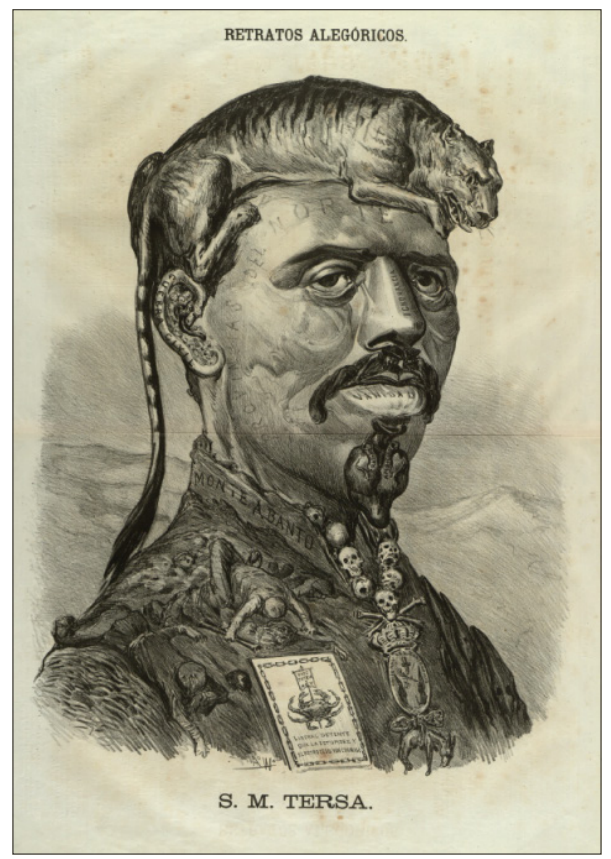

\section{España bien vale una caricatura}

Los semanarios que citamos se inscriben dentro del período denominado "Sexenio Democrático" o "Revolucionario", que abarcó los años que van del 1868 al 1874. Es decir, desde la revolución Septembrina o Gloriosa, con la que el reinado de Isabel II de Borbón daba a su fin y, con ello, desaparecía la dinastía borbónica de España, hasta el pronunciamiento de Sagunto, que devolvía a los Borbones al trono.

Tras la revolución de 1868, confluyeron dos circunstancias que favorecieron un desarrollo sin precedentes de la caricatura política en el ámbito español y, por lo tanto, la creación de ejemplos tan singulares como aquellos a los que se dedica este artículo:

Por un lado, el Gobierno provisional, encabezado por el impertérrito espadón Francisco Serrano, permitió una libertad de imprenta nunca antes vista. Anteriormente, siendo reina Isabel II, a medida que la prensa satírica y sus dibujos cobraban una mayor resonancia, se fue endureciendo la regulación sobre las publicaciones periódicas. Es más, a partir de la promulgación de la Ley de Nocedal en $1857^{5}$, cuyo nombre obedece a su creador, la legislación atendió por primera vez de manera independiente a la parte gráfica: «las viñetas que se hayan de estampar en el cuerpo de

\footnotetext{
5 A través de esta regulación, se establecía la existencia de un fiscal de Imprenta quien, nombrado por el ministro de Gobernación, se encargaba de recoger un ejemplar del periódico, dos horas antes de ser distribuido, para hacérselo llegar a un tribunal ordinario, encargado de aprobar su venta. Véase Gómez Aparicio, Pedro: Historia del periodismo..., p. 450.
} 
un periódico o de otro impreso cualquiera $»^{6}$. Y así fue hasta que el Decreto del 23 de octubre de 1868 estableciese que «todos los ciudadanos tienen derecho a emitir libremente sus pensamientos por medio de la imprenta, sin sujeción a la censura ni a ningún requisito previo»?.

El otro aspecto que benefició al género de la caricatura fue que las intenciones de este nuevo gobierno provisional, en el que tantas esperanzas de cambio habían sido depositadas, no fueron exactamente las deseadas:

La mayoría de las publicaciones satíricas del último tercio de siglo, de ideología liberal, compartía el deseo de la instauración de la república en España.

¡Oh! Cuán bueno es Dios, que permite que esta hidalga nacion tenga reyes cesantes como doña Isabel, reyes legitimados como D. Alfonso, reyes imaginarios como D. Carlos, reyes desinteresados como Montpensier [...] ¡Oh, los reyes, los reyes! Ellos son nuestros protectores [...] Nosotros jingratos! los aborrecemos [...] $¡ A$ Ah! ¡Somos unos perversos, y merecemos con justicia y como castigo á nuestra insensatez, sufrir los horrores de una república bien organizada! ¡Que venga, Señor, si es tu voluntad, y si no... tambien, porque es la mía! ${ }^{8}$.

En los meses que precedieron y siguieron a aquel agitado mes de septiembre de 1868 , las caricaturas que se imprimían transmitían la posibilidad, cada vez más tangible, de una distinta y nueva forma de gobierno. Así, se desprestigiaba la figura de la Reina, comenzando una tendencia que continuaría tiempo después de la revolución, muestra de lo cual es la burla que publicaba La Carcajada en 1872:

[...] Y ¿cómo hemos respondido los españoles a su cariño? Con caricaturas, con epigramas, matando de hambre á sus periódicos [...] y dejándole, en fin, el corazón lleno de amargura y los bolsillos muy flojos?.

También se atacaba a todo aquello que representase la monarquía, incluidos los valores e instituciones tradicionales que la rodeaban, destacando en este sentido la Iglesia y los miembros del clero. Es muy clarificador lo que ocurrió con el ya célebre semanario Gil Blas: a partir de octubre de 1866, para evitar la censura, se vieron limitados a incluir entre sus páginas viñetas humorísticas solo de carácter costumbrista, rompiendo con su precedente temática política. Esta situación cambió en 1867 después de que, por solicitud de sus lectores, les fuera concedido el permiso de volver a la sátira política: «A petición de un gran número de suscritores [sic] hemos puesto el depósito que exige la ley, y en cuanto recibamos la autorización del señor Gobernador, saldrá GIL BLAS con carácter político» ${ }^{10}$. Comenzó entonces la tercera época de Gil Blas que, haciendo tímidas incursiones sobre asuntos de política internacional, terminó por retratar a la reina patas arriba (figura 6).

Fernández Sarasola, Ignacio: La legislación sobre historieta en España, Sevilla, ACyT, 2014, pp. 21 y 22.

7 Cendán Pasos, Fernando: Historia del derecho español de prensa e imprenta (1502-1966), Madrid, Editora Nacional, 1974, p. 140.

8 Matoses, Manuel: “Conjunción”, en Gil Blas, 392 (6 de agosto de 1871), p. 2.

9 "España", en La Carcajada, 15 (6 de mayo de 1872), p. 4.

10 [Sin título], Gil Blas, 114 (3 de noviembre de 1867), p. 4. 
Figura 6. Daniel Perea: «GALERÍA DE PINTURAS DE GIL BLAS. Proyecto de un cuadro que representa la revolucion española, para el Museo del porvenir», Gil Blas, 101 (22 de octubre de 1868).

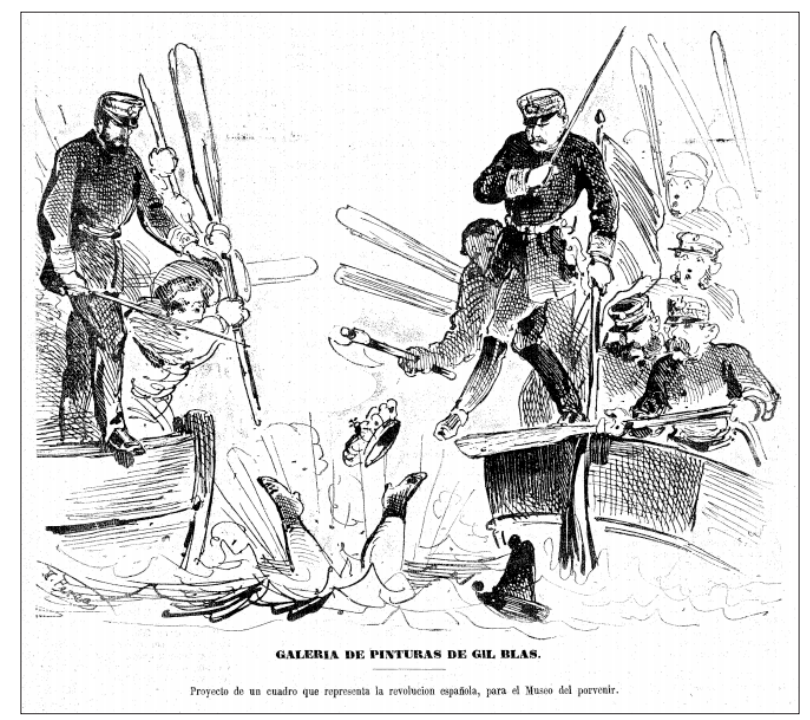

Pero resultó que aquellos militares y políticos que habían organizado la Gloriosa quizás riesen con aquellas caricaturas hasta cierto punto y quizás tuviesen dudas de que lo que necesitase el país fuera una república. De este cambio de parecer se dio cuenta un desengañado sector del pueblo cuya voz fue amplificada por los periódicos satíricos. Estos focalizaron sus incisivos dibujos hacia los miembros del Ejecutivo, y de la escena política en general, y hacia los pretendientes al trono de España -pues, tras someterse a votación en las Cortes Constituyentes, ganó por mayoría la monarquía como forma de gobierno-. La inestabilidad que siguió a la Septembrina -sirva como demostración la mención de los sistemas políticos que se sucedieron en tan solo seis años: un gobierno provisional, una regencia, una monarquía parlamentaria, una república y una dictadura- continuó alimentando la sátira. Y así «la deformación grotesca lo abarcará todo [...] La historia del siglo XIX marca el ritmo al que crece el género» ${ }^{11}$. Como consecuencia, reapareció la censura:

[...] eso de reirse á cuello tendido, segun mis cristianos propósitos, de lo que ciertas gentes aplauden, y yo con el público imparcial silbo, es mas peliagudo de lo que parece ${ }^{12}$.

No obstante, el ímpetu con el que embestía el progresivo movimiento de crítica, cultivado en aquel breve período de libertad tras la Revolución, hacía a los semanarios reponerse de la actuación censora. Las sanciones iban, no solo durante el Sexenio, desde la prohibición de números completos, la multa o la suspensión de

11 Bozal, Valeriano: "El grabado...", p. 321.

12 "Á lo que vengo", en La Carcajada, 1 (17 de enero de 1872), p. 1. 
un semanario ${ }^{13}$ - contra lo cual era frecuente el renacimiento de la publicación con un título diferente-, hasta la prisión de algún miembro de la redacción. Esto último afectaba en mayor medida a quienes tuviesen más responsabilidad dentro del periódico, aunque tampoco estaban a salvo los colaboradores. Se reproduce en Gil Blas un fragmento de un artículo publicado por el escritor portugués Julio César Machado en el que cuenta que, estando en Madrid, le había llegado el rumor de que Luis Rivera -director del semanario y escritor- y Manuel Palacio - escritor colaborador-, habían sido encarcelados. Finalmente, el protagonista da con un amigo suyo que le desmiente que Rivera estuviese en el Saladero -como se denominaba a la cárcel dando cuenta de la función original del edificio como saladero de cerdos- a la vez que hace notar lo habitual de estas estancias: «¡Ah! sí, es verdad; ¡eh! un leve episodio; ¿y qué es eso en la vida de un español? Ha estado preso, pero ya está libre» ${ }^{14}$.

Huelga decir que los dibujantes, que eran un miembro más dentro de las redacciones, no eran menos en este aspecto. Según Méndez Rutlán, Eduardo Sojo -el autor de las caricaturas de Juan Moreno Benítez y de Montpensier aparecidas en El Caos-, fue el caricaturista que más veces sufrió la censura por sus dibujos ${ }^{15}$. Además, fue autor de artículos y dueño de alguna publicación, como La Marsellesa, El Noventa y Tres y Don Quijote. Y por todo el conjunto fue perseguido por las autoridades, viéndose forzado a emigrar de ciudad y de continente ${ }^{16}$. Anteriormente había sido encarcelado por no haber pagado la fianza obligatoria al comenzar a publicar su periódico El Noventa y Tres ${ }^{17}$.

\section{Publicaciones para su público}

La continuidad de los periódicos fue posible gracias a su público, fiel jaleador de las críticas de la prensa satírica, pues reconocían entre sus páginas lo que demandaban: una contestación al insultante rumbo al que estaba siendo conducido el país, emitida de forma directa y con un donaire característico; la agilidad propia de estas publicaciones influyó en la prensa seria ${ }^{18}$.

Los directores conocían muy bien la inclinación sus lectores por las caricaturas, «clave del producto y el factor determinante de su posible éxito comercial» ${ }^{19}$. Atendiendo a la "Advertencia" de El mundo cómico, uno de muchos ejemplos, -«Desde

13 Javier Orcajo apunta cómo la revista La Flaca fue suspendida en el último trimestre de 1870, «durando la sanción el tiempo exacto en que el italiano [Amadeo de Saboya] fue buscado y aupado por el militar [Juan Prim], que de esta forma se quitaba de en medio una voz crítica». Véase Orcajo, Javier: "La prensa satírico-gráfica en las otras abdicaciones borbónicas. Isabel II y la Revolución de septiembre de 1868" [en línea], en Tebeosfera, 12 (2008). [Consulta: 2 de febrero de 2017]. Disponible en: https://www.tebeosfera.com/documentos/la prensa satirico-grafica_en_las_otras_abdicaciones_borbonicas.isabel_ii_y_la_revolucion_de_septiembre_de_1868. html.

14 "Cabos sueltos", en Gil Blas, 20 (12 de enero de 1868), p. 3.

15 Méndez Rutllán, María: "Prensa madrileña de la revolución, 1868-1874. Eduardo Sojo caricaturista político", en Villa de Madrid, 60 (1878), p. 64.

16 Laguna Platero, Antonio. y Martínez Gallego, Francesc Andreu: "Eduardo Sojo...” [en línea], pp. 117 y 123. [Consulta: 28 de diciembre de 2016]. Disponible en: https://idus.us.es/xmlui/handle/11441/33051.

17 Laguna Platero, Antonio. y Martínez Gallego, Francesc Andreu: “Eduardo Sojo...” [en línea], p. 116. [Consulta: 28 de diciembre de 2016]. Disponible en: https://idus.us.es/xmlui/handle/11441/33051.

18 Seoane, María Cruz: Historia del periodismo en España. 2. El siglo XIX, Madrid, Alianza, 1989, p. 259.

19 Laguna Platero, Antonio y Martínez Gallego, Francesc Andreu: "Imaginarios femeninos a través de la prensa satírica: de Gil Blas a Don Quijote", en Revista de la Asociación Española de Investigación de la Comunicación, II,3 (2015), p. 51. 
el próximo número aumentaremos todo lo posible la parte literaria de EL MUNDO CÓMICO, siempre que las condiciones de las viñetas lo permitan $\rangle^{20}$ - observamos que el incremento de artículos estaba supeditado a la presencia de la imagen; aunque en tono de broma, ya dice mucho no solo sobre el interés que despertaban entre los lectores los dibujos, sino sobre la importancia de la imagen sobre la palabra impresa: este periódico en particular solía presentar en seis o siete de sus ocho páginas una viñeta. El esfuerzo de las revistas por llamar la atención sobre sí mismas es una constante en vista de la cada vez más amplia oferta de publicaciones del estilo. Así, el efímero semanario barcelonés El Lio - de tan solo siete números de duración- aludía de esta manera a su retrato de Savalls, del que venimos a hablar, que había sido impreso la semana anterior:

En vista de la singular aceptacion que ha obtenido el retrato alegórico, publicado en el número anterior, nuestro dibujante, con el doble objeto de complacer al público y á la empresa editorial, ha borroneado otros retratos por el estilo de aquel, que estamos seguros que llamarán la atencion de nuestros suscritores [sic], como han llamado la nuestra, y que publicaremos de vez en cuando ${ }^{21}$.

Además de encabezar el ejemplar, de forma que era la primera noticia que podía leerse, rememoraba el éxito del dibujo anterior para después anunciar próximos retratos. Por último, pretendían atraerse más compradores asegurando la sorpresa que iban a causar las próximas entregas. Cabe suponer que, como parte de la estrategia comercial, algunas publicaciones procuraran maquillar la mediocridad de una imagen y de su artífice con anuncios como el anterior... Por suerte, la advertencia de $E l$ Lio era cierta y se confiaba en ello desde su redacción, pues contaban entre sus filas con Tomás Padró como dibujante, quien era «garantía de éxito»» ${ }^{22}$.

El público comprador de semanarios satíricos se encontraba, sobre todo, en una parte de la sociedad española; aquella que pudiese costearse una suscripción de en torno a los seis y dieciséis reales al trimestre y que casase con los ideales liberales hegemónicos ${ }^{23}$ de la prensa satírica ilustrada: la burguesía. De hecho, el nacimiento de la prensa estuvo vinculado, desde sus orígenes, a esta clase social. Para el caso español, fue en el Cádiz de las Cortes de principios del siglo XIX donde y cuando los periódicos, como «vehículos de ideas», se erigieron instrumento unificador de la lucha contra el feudalismo ${ }^{24}$.

Por lo general, tanto dibujantes como consumidores pertenecían al mismo estrato social y tenían un acceso similar a la cultura y, por lo tanto, al conocimiento de obras como las de Giuseppe Arcimboldo u otros, pues ya en otras ocasiones los caricaturistas se habían inspirado en obras de la "alta cultura" (figuras 7 y 8, que muestran una versión de La rendición de Breda y del Hércules Farnesio, respectivamente).

20 “Advertencias”, en Mundo Cómico, 139 (27 de junio de 1875), p. 8.

21 [Sin título], El Lio, 2 (14 de febrero de 1874), p. 1.

22 Bori, Salvador: Tres maestros del lápiz. Padró, Planas y Pellicer, Ediciones Librería Milla, 1945, p. 30.

23 Esto no quiere decir, ni mucho menos, que toda la prensa satírica coincidiese en ideología. Véase Seoane, María Cruz: Historia del periodismo..., p. 280.

24 Laguna Platero, Antonio: "El espejo de la revolución burguesa”, en Manuel Chust (ed.): De la cuestión señorial a la cuestión social, Valencia, PUV, 2002, p. 128. 
Figura 7. Francisco Ortego: «La cesión del siglo», Gil Blas, 24 (23 de diciembre de 1866).

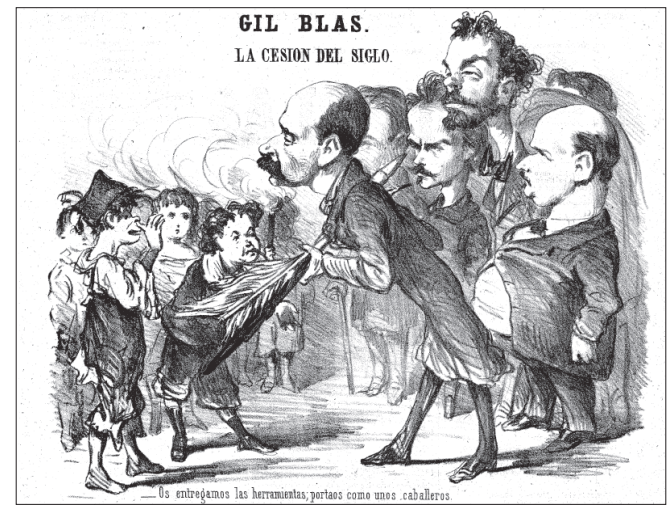

Figura 8. $\mathrm{A}^{\circ} \mathrm{W}^{\circ}$ (Tomás Padró): «Divinidades paganas, dedicadas á los paganos», La Flaca, 49 (23 de enero de 1872) [Detalle].

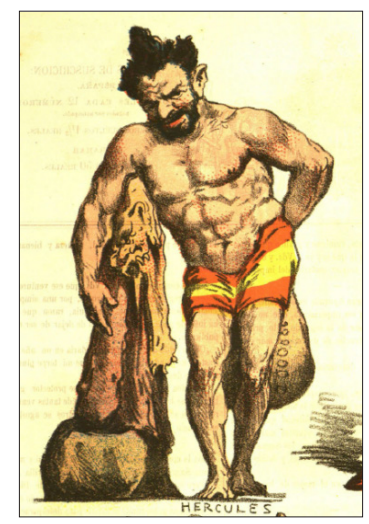

No sería extraño que estos guiños hacia el arte de la "alta cultura" tuviesen una cierta importancia táctica que fuese más profunda que el mero atractivo de una imagen deformada; o que las revistas tratasen de proporcionar al público burgués, estigmatizado desde la aristocracia por su "vulgaridad"25, no solo la posibilidad de auto-complacerse con el descubrimiento de este guiño - arcimboldesco para el caso-, sino además dar cuenta de la apropiación y reinterpretación por parte de un género surgido en el seno de la burguesía de aquello que otrora fue cosa de la aristocracia.

Ahora bien, tengamos en cuenta el alto grado de analfabetismo de la población española y su consumo de la ya entonces tradicional literatura de cordel y de los sueltos -parientes de los periódicos-, que estaban ilustrados con grabados para facilitar su acceso ${ }^{26}$. Sumemos el

25 Considero muy ilustrativo para este particular hablar en términos de moda en cuanto a que, con el auge de la burguesía, en este siglo XIX, la aristocracia veía amenazada su distinción, pues una clase inferior a ella ya podía permitirse adquirir un atuendo similar. El resultado fue que desde la aristocracia se atacase a la burguesía en términos que venían a decir que la última era una simple mala copia. Véase Díaz Marcos, Ana María: La edad de seda: representaciones de la moda en la literatura española (1768-1926), Cádiz, Universidad de Cádiz, 2006, pp. 152-167.

26 Casas Delgado, Inmaculada: Romances con acento andaluz. El éxito de la prensa popular (1750-1850), Sevilla, Fundación Pública Andaluza Centro de Estudios Andaluces, 2012, p. 45. 
poder aglutinador de la prensa y la militancia que define a la prensa satírica ${ }^{27}$ y recordemos la creciente importancia de las caricaturas. El resultado es claro: aunque quien comprase las revistas fuese, por las razones aludidas, la burguesía, restringir su consumo a esta fracción de la población sería arriesgado. Se exponían ejemplares en los escaparates de las librerías-hay noticias en las que los periodistas que publican sus protestas por mandatos que ordenaban retirar depende de qué publicaciones a causa de sus caricaturas ${ }^{28}$, , o podían leerse en los cafés $\mathrm{o}$, incluso, en los urinarios públicos, sobre los que se aprobó asimismo un modelo de espacio para la venta de periódicos ${ }^{29}$.

A falta del invento de la televisión y de la normalización de la fotografía, las personalidades de entonces eran dadas a conocer a través del dibujo ${ }^{30}$. Si este dibujo era una caricatura, esto es, deforme, y lo que se buscaba desde las redacciones, más allá de las pretensiones comerciales, era fortalecer la mala opinión de la política del país, ¿qué método mejor podrían desear para exhibir la mala gestión que sufría el del país? La ridiculez de todos estos personajes era patente para todos los que viesen las caricaturas, aún sin desentrañar todos los significados del dibujo o sin leer los maliciosos artículos y versos que completaban el conjunto de las revistas.

\section{La importancia de llamarse "artista"}

En esta década de 1870 en la que se inscriben los dibujos de Eduardo Sojo y de Tomás Padró, la caricatura ya no estaba subordinada a un texto, a modo de ilustración, sino que era concebida como un ente autónomo. El primer ejemplo de este fenómeno de independencia del dibujo lo encontramos en el ya varias veces citado Gil Blas, el cual, desde su aparición en $1864^{31}$, «confirma la mayoría de edad de la prensa satírica ilustrada con caricaturas $\rangle^{32}$. Fue la consecuencia de la notoriedad que fue adquiriendo entre los lectores y lo que provocó que los dueños de las publicaciones dedicasen mayor protagonismo a la imagen, cediéndole más espacio, cuidando su presentación y confiándosela a los mejores artistas, como lo fue Padró, cuya firma " $\mathrm{A}^{\circ} \mathrm{W}^{\mathrm{o}}$ " aparecía en varias publicaciones del momento.

El artista barcelonés, después de trasladarse desde su ciudad natal, en donde había estado matriculado en la escuela de dibujo de la Lonja de Barcelona y en la academia privada de Claudio Lorenzale, en 1860 marchó a la capital -por segunda vez-y completó sus estudios artísticos en la Real Academia de San Fernando ${ }^{33}$. Fontanals del

27 Laguna Platero, Antonio. y Martínez Gallego, Francesc Andreu: “Imaginarios...," p. 51..

28 Al pie de una viñeta de El Noventa y Tres: «El boceto de esta caricatura ha sido retirado del escaparate de una librería por órden amistosa del señor ministro». Véase El Noventa y Tres, 3 (5 de diciembre de 1870), p. 3.

29 Simón Palmer, María del Carmen: "La publicidad y la imagen en Madrid (1840-1874)", en Marie-Linda Ortega (ed.): Ojos que ven, ojos que leen. Textos e imágenes en la España isabelina, Madrid, Visor, 2004, pp. 21 y 24.

30 Laguna Platero, Antonio: "El poder de la imagen y la imagen del poder" [en línea], en IC Revista Cientifica de Información y Comunicación, 1 (2003), pp. 111 y 112. [Consulta: 19 de enero de 2017]. Disponible en: https:// idus.us.es/xmlui/handle/11441/18275.

31 En 1859, fue fundado el semanario El Nene. Se ha planteado si, tratando un mismo tema, los dibujos de El Nene pudieron haber sido concebidos antes que los textos correspondientes. Además, algunas de sus caricaturas tan solo rendían cuentas a un pie de imagen, aunque se trataba de casos excepcionales. Estas son algunas de las razones por las que puede considerársele como la «antesala» de Gil Blas. Véase Alonso, Cecilio: "Épica y sátira en los dibujos de Francisco Ortego en torno a la Guerra de África (1859-1860)”, en Borja Rodríguez y Raquel Gutiérrez (coords.): Literatura ilustrada decimonónica: 57 perspectivas, Santander, Publican, 2011, pp. 26 y 29.

32 Laguna Platero, Antonio: "El poder..." [en línea], p. 116. [Consulta: 19 de enero de 2017]. Disponible en: https://idus.us.es/xmlui/handle/11441/18275

33 Fontanals i del Castillo, Joaquim: Recuerdo al artista Tomás Padró, Tribútanle otros de los admiradores de su ingenio, Barcelona, Tipografía Litográfica C. Verdaguer, 1877, pp. 2 y 3. 
Castillo cuenta que era además arquitecto y parece ser que prefería ser denominado como tal antes que como dibujante ${ }^{34}$. Por su parte, Bori, si bien no hace referencia a esta segunda profesión de Padró, sí insiste en sus incansables deseos de ser pintor ${ }^{35}$. Arquitecto o no, estas puntualizaciones ilustran de algún modo la baja estima hacia el trabajo en semanarios. Es muy pertinente la fábula del murciélago empleada por Pascal Ory para referirse a los dibujantes de prensa: el murciélago es pájaro y ratón, como el caricaturista es artista y periodista, de modo que es considerado de forma condescendiente por ambas ramas ${ }^{36}$.

Desde el punto de vista artístico, existía cierta desconsideración hacia la profesión, ratificada por la "doble inferioridad" achacada al trabajo en prensa: se trata de una labor reproductible e instrumentalizada ${ }^{37}$. Han quedado como testigo de este sentimiento las palabras del ilustrador Apel.les Mestres, que ponen de manifiesto la frustración que sentía otro de los afamados dibujantes de la época, José Luis Pellicer, por no haber podido llegar a dedicarse a la pintura profesionalmente, como fue su eterno deseo:

[...] no podía menos de comparar la resplandeciente aureola que rodeaba á aquellos [pintores], con la obscuridad que envolvía á los que [...] cultivaban la ilustración de libros y periódicos, tan mal retribuidos por los editores como tratados desdeñosamente por el público ${ }^{38}$.

A pesar de todo, los propios periódicos, cuando se referían a sus colaboradores gráficos, los presentaban como artistas, como ocurría en la advertencia con la que $L a$ Correspondencia del Diablo hablaba de su cáustico dibujante, $«$ Cham ${ }^{39}$ :

Causas ajenas a nuestra voluntad impidieron que la lámina correspondiente al número anterior produjera todo el efecto artístico que el intencionado lápiz de su autor supo darla al trasladar su inspiración a la piedra $[\ldots]^{40}$.

Sojo, al contrario que Padró y que Pellicer, al no haber cursado ninguna formación reglada, no tuvo por qué albergar ningún sentimiento de desengaño. Fue un ávido autodidacta, siempre dispuesto a ejercitar su dibujo con los maestros de museo; no son casuales, por su fidelidad, las reinterpretaciones de cuadros de historia que publica sobre todo en su Don Quijote, de dos décadas después de estos arcimboldos. Asimismo, tampoco descuidó a los artistas de su presente entre los que se encontraba el gran caricaturista Francisco Ortego, otro pintor frustrado, por el cual manifestó su admiración ${ }^{41}$.

Expuestas una y otra circunstancias, sería lógico pensar en que los dibujantes empleasen lo que estaba de su mano, esto es, sus viñetas, para poner en valor su arte. Que aquellos que poseían formación académica, como Padró, citasen por ello a otros

34 Fontanals i del Castillo, Joaquim: Recuerdo..., p. 1.

35 Bori, Salvador: Tres maestros..., pp. 23-25.

36 Ory, Pascal: "Introduction", en VV. AA.: La caricature... et si c'était sérieux? Décryptrage de la violence satirique, París, Noveau Monde, 2015, p. 15.

37 Ory, Pascal: "Introduction", p. 15.

38 Mestres, Apeles: "Pellicer", en La Lectura, 1(1902), p. 590.

39 No hay que confundirle con el caricaturista francés Amédée de Noé del que, presumiblemente, pudo tomar el pseudónimo.

40 “Advertencia", en La Correspondencia del Diablo, 2 (10 de abril de 1872), p. 1.

41 Laguna Platero, Antonio y Martínez Gallego, Francesc Andreu: "Eduardo Sojo..." [en línea], p. 118. [Consulta: 28 de diciembre de 2016]. Disponible en: https://idus.us.es/xmlui/handle/11441/33051. 
artistas o realizasen un despliegue de sus capacidades -la presencia de figuras de dibujo académico en las caricaturas del barcelonés es reincidente (figuras 9 y 10)$y$, de este modo, buscasen ennoblecer y legitimar su oficio dentro de la Historia del Arte. De otra parte, entenderíamos que los caricaturistas como Sojo, al servirse como modelo del dibujante y pintor Ortego y de la Historia del Arte, reconociesen como pariente directo al "gran arte".

Figura 9. $\mathrm{AVV}^{\circ}$ (Tomás Padró): «La libertad está asegurada en manos del general Prim», $E l$ Guirigay del 70, 12 (24 de junio de 1870).

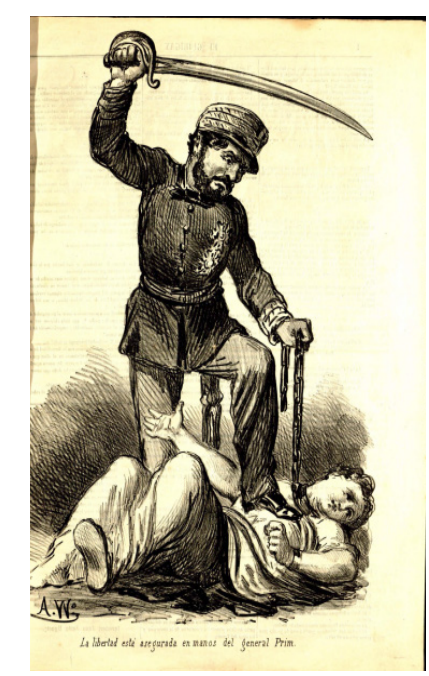

Figura 10. $\mathrm{AVV}^{\circ}$ (Tomás Padró): Sin título, La Flaca, 90 (4 de junio de 1871) [Detalle en el que representa a la República].

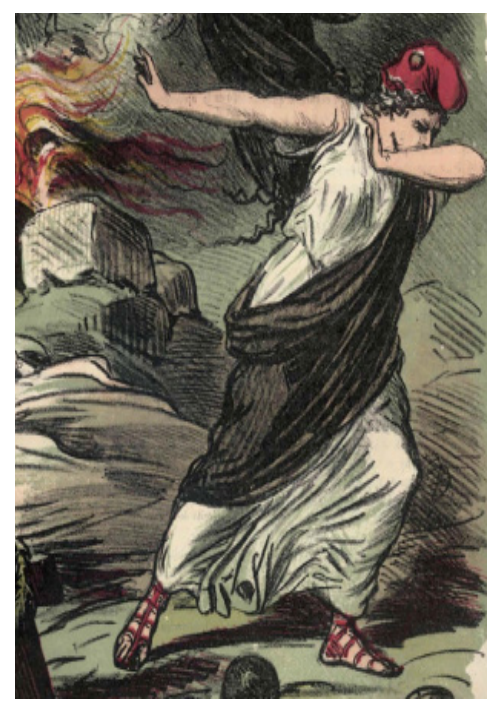


No obstante, no hay que desechar la idea de que, ya que eran humoristas gráficos, le diesen la vuelta a la imponente y seria aura de la pintura de museo, que la profanasen; a la postre, la caricatura implica un cambio de la percepción, otra visión.

Otra opción sería que, simplemente, referenciasen otras creaciones confiando en que resultase una caricatura que llamase la atención de los compradores; publicar dibujos compuestos de otros dibujos podría ser un buen reclamo.

Ninguna de las anteriores motivaciones tuvo por qué ser excluyente. Y si lo hubiesen sido, y a falta de tener ningún testimonio al respecto por parte de los artistas -o al menos que sepamos- lo único que puede aducirse es la existencia de citas, con los dibujos como única prueba. Así pues, observando las cinco caricaturas, se reconoce la huella de Arcimboldo, que fue el iniciador de este tipo de retratos.

\section{4. ¿Inspiración directa o indirecta?}

Las invenciones del artista lombardo habían servido de modelo a otros posteriores a él ${ }^{42}$ para crear obras nuevas «sin abandonar su estilo, sin ser imitadores. Seguidores sin separarse de su tiempo, su cultura y su sus circunstancias en beneficio de su ejemplo» ${ }^{43}$. Existe, al menos desde el punto de vista formal, un lazo de unión viable entre estas y las cinco caricaturas: unas estampas sobre Isabel II (figura 11) -producidas, por cierto, en Italia y después reproducidas en versión fotográfica por artistas españoles, en formato de carte de visite. Difundidas en los momentos finales de su reinado, la de los tristes destinos aparece en ellas bien distinta a cómo nos la mostrase su pintor de cámara, Federico de Madrazo. Por si no era suficiente su nuevo aspecto, incluía esta versión española la siguiente leyenda:

El verdadero retrato de la última de los Borbones. Protectora la más fanática del poder temporal del jesuitismo y de la opresión. Reservó los cadalsos y las cárceles para los hombres de mérito que sostuvieron su trono, tiranizó y empobreció al pueblo que con su sangre le había dado la corona y le cubrió de escarnio ante la Europa $^{44}$.

Para aquel entonces, nuestros dos caricaturistas ya trabajaban como tal y perfectamente pudieron haberse servido de ellas como modelo.

Asimismo, fue factible que ambos conociesen reproducciones de las obras de Arcimboldo y, al menos, un original, pues en la Real Academia de Bellas Artes de San Fernando se conserva uno de los cuadros de la serie de las Estaciones del pintor cinquecentista: la Primavera (figura 12). No se sabe cuándo ingresó en la institución madrileña, pero sí se nos dice que pudo haber formado parte de las obras que decora-

42 «The Arcimboldesques». Véase Hulten, Pontus: "Three different kinds of interpretations", en Hulten, Pontus (ed.): The Arcimboldo Effect. [Cat. exp.]. Venecia, Palazzo Grassi, 1987, p. 19. El catálogo de la exposición realiza un recorrido desde el siglo XVI hasta el siglo XX, abarcando las creaciones que siguieron la estela de múltiples lecturas de Arcimboldo.

43 Inglés en el original. Véase Falchetta, Piero (ed.): “Anthology of Twentieth Century texts", en Hulten, Pontus (ed.): The Arcimboldo..., p. 208.

44 Burdiel, Isabel (ed.): Los Borbones en pelota, Zaragoza, Institución Fernando el Católico, 2012, p. 57. 
ban la habitación de Felipe $\mathrm{II}^{45}$, a la sazón primo y yerno de Maximiliano II, primer destinatario de la serie. Es decir, cabe la posibilidad de que la residencia del óleo en España se remonte varios siglos atrás.

Figura 11. Caricatura de Isabel II, ca. 1868.

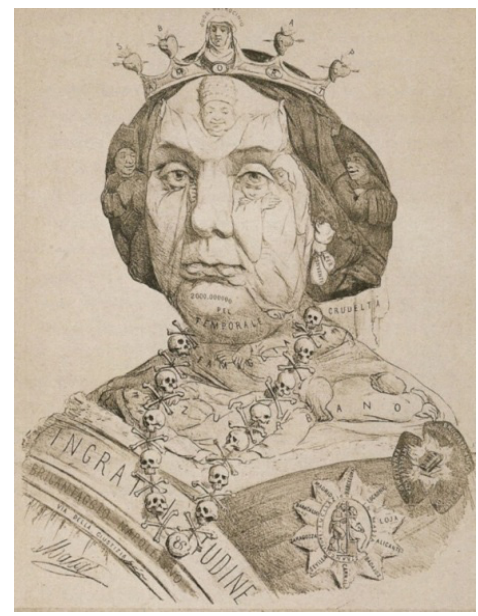

Figura 12. Giuseppe Arcimboldo: La Primavera, 1563. Real Academia de Bellas Artes de San Fernando, Madrid.

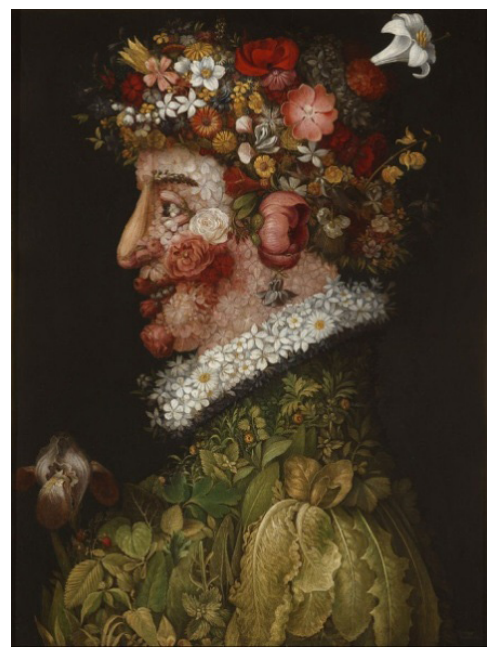

El filósofo francés Roland Barthes compuso en 1978 un precioso acercamiento a las cabezas compuestas del pintor milanés en "Arcimboldo o el retórico y el mago" ${ }^{4}$. En

45 Bonet Correa, Antonio (et al.): Real Academia de San Fernando. Guía del Museo, Madrid, Real Academia de Bellas Artes de San Fernando, 2012, p. 44.b.

46 Para este artículo hemos consultado la siguiente edición: Barthes, Roland: "Arcimboldo o El retórico y el mago", en Barthes, Roland: Lo obvio y lo obtuso. Imágenes, textos, voces, Barcelona, Paidós, 1992. ( $1^{\mathrm{a}}$ ed. 1982), pp. 133-151. 
él establecía que el artista transformaba la pintura en una lengua en tanto que la dota de una doble articulación: a partir de la combinación de objetos independientes -que corresponderían a las palabras de una lengua- da lugar a un discurso, esto es, las cabezas. A su vez, cada una de estas palabras, así como la visión en conjunto de cada efigie, se descompone en líneas y puntos o en unidades insignificantes que equivaldrían a los fonemas ${ }^{47}$. Lejos de que los óleos sean enunciados simples, Arcimboldo juega con todas las palabras de su lengua de imágenes, modifica su significado:

[...] a su manera, es un retórico: con sus Cabezas, arroja todo un paquete de figuras retóricas dentro del discurso de la Imagen: la tela pasa a ser un auténtico laboratorio de tropos $^{48}$.

Tomemos las palabras de Barthes como guía y leamos las cinco láminas que presentamos. Así iremos descubriendo qué tienen en común y en qué difieren de Arcimboldo y puede que averigüemos si pudieron haber tomado la Primavera de la Real Academia como modelo.

Consideremos, en fin, a Tomás Padró y a Eduardo Sojo como retóricos del discurso deformado que es la caricatura.

\section{Otro laboratorio de tropos}

Señalando la función de juego de salón que tenían las cabezas compuestas de Arcimboldo para la corte del emperador Maximiliano, Barthes compara las composiciones con el juego de las familias de su infancia-que consiste en juntar a todos los miembros de cada una-, poniendo el ejemplo del Invierno: «Se nos pide que reconstruyamos la familia del Invierno [...] toda la "familia" de los productos de la estación muerta ${ }^{49}$. Con muy diferente intención, los dos artistas de semanario proponían reconstruir la «familia» de las acciones que se les recriminaba desde la prensa a los personajes de las caricaturas, ya que resultan ser una suerte de resumen de sus trayectorias respectivas. Emplearon para ello una imaginería ya asimilada por los lectores a lo largo de los años durante los que se venía desarrollando el género de la caricatura ${ }^{50}$. El público se fue habituando a los rasgos exagerados y, lo que nos interesa en este momento, se familiarizó con todo un arsenal ${ }^{51}$ de símbolos para identificar a personajes, instituciones o situaciones de su momento. Igualmente, y a pesar de que parezca lo contrario con aquel juego infantil de las familias, no solo hay frutas, flores, animales, etc. en las cabezas del pintor de las Estaciones:

47 Barthes, Roland: “Arcimboldo...,", pp. 137 y 138.

48 Barthes, Roland: "Arcimboldo...,", p. 139.

49 Barthes, Roland: "Arcimboldo...", p. 133.

50 «La gran cantidad de imágenes que ofrecen los periódicos requiere un aprendizaje por parte del lector». Véase Ortega, Marie-Linda: "El arte de Ortego en la prensa", en Marie-Linda Ortega (ed.): Ojos que ven ..., p. 205.

51 Es Gombrich quien alude a un «arsenal del caricaturista» refiriéndose los recursos simbólicos de los que se sirve el caricaturista para realizar unos dibujos que se inscriben en un contexto delimitado. Véase Gombrich, Ernst Hans: "El arsenal del caricaturista", en Gombrich, Ernst Hans: Meditaciones sobre un caballo de juguete, Barcelona, Seix Barral, 1968, p. 163. 
[...] todo es metáfora [...] Nunca hay nada denotado, ya que los rasgos [...] que sirven para componer una cabeza, tienen previamente un sentido, y este sentido está desviado hacia otro sentido, arrojado, en cierto modo, más allá de sí mismo (eso es lo que etimológicamente, quiere decir "metáfora") ${ }^{52}$.

Mientras que los caricaturistas empleaban figuras retóricas con un significado previo, Arcimboldo conseguía asignar a los objetos un sentido metafórico en función del lugar que ocupasen en el retrato. Con esto, Barthes equipara a Arcimboldo con un poeta $-\mathrm{u}$ «obrero del lenguaje» $\rangle^{53}$ - quien, a través de sus cabezas, convierte su pintura en una lengua ${ }^{54}$ de la cual explota sus recursos retóricos hasta convertir su pintura en todo un laboratorio de tropos ${ }^{55}$ de múltiples lecturas. Por ejemplo, los lienzos de la serie de las Estaciones constituyen, los cuatro, una sola alegoría de los Habsburgo -las cuatro estaciones son hegemónicas como el propio Imperio ${ }^{56}$. Al tiempo, son una mímesis metafórica de algunos miembros de la dinastía quienes además, y de manera autónoma, simbolizan las virtudes imperiales ${ }^{57}$.

Por su parte, Eduardo Sojo y Tomás Padró confeccionaron sus cabezas autónomamente; no obstante, aunarlas como una alegoría de agravantes de la inestabilidad de España, no sería inadecuado, como tampoco lo sería convertirlas en personificaciones de la corrupción, la ambición, el fanatismo, la guerra... Comprenderlas a día de hoy, dada la condición temporal de la caricatura, en este caso política, trae consigo que haya que emprender un estudio que revele, como mínimo, el hacia quién, el porqué y el cómo de la sátira. Con todo, esta es una apreciación general. Existen dibujos, llamémoslos transtemporales $^{58}$, protagonizados -y el papel es muy significativopor personificaciones o símbolos cuyo mensaje puede entenderse sin necesidad de investigación alguna o, más aún, aplicarse a las circunstancias actuales (figuras 13 y 14).

Pretender analizar todos y cada uno de los elementos de los cinco dibujos, aparte de que nos entretendría demasiado, no es posible dada la mala calidad de las reproducciones de las viñetas de El Caos. Empero, sí procuraremos exponer los detalles más significativos, abordando de manera conjunta las dos sátiras de Antonio de Orleans por un lado, ya que por ser la misma persona poseen características análogas, y las de Francisco Savalls y Carlos VII por otro, pues a ambos se les dirigen reproches similares por su condición de carlistas. En cualquier caso, desarrollaremos este ejercicio siempre que el lector permita que justifiquemos nuestras interpretaciones con la ambivalencia que implica caminar por el terreno de la ironía, aquella que dice sin decir, diciendo ${ }^{59}$.

52 Barthes, Roland: “Arcimboldo...,", p. 141.

53 Barthes, Roland: “Arcimboldo...”, pp. 137 y 138.

54 Barthes, Roland: “Arcimboldo...", p. 138.

55 Barthes, Roland: "Arcimboldo...", p. 139.

56 Hulten, Pontus: "Three different...,", p. 22.

57 Hulten, Pontus: "Three different...", p. 22.

58 Baudelaire señalaba dos clases de caricaturas: «Unas solo tienen la vigencia del hecho que representan [...] pero las otras [...] contienen un elemento misterioso, duradero, eterno, que despierta la atención de los artistas», sin embargo, aquellas a las que nos referimos no tienen un carácter tan universal como el que dota el poeta al segundo grupo. Véase Baudelaire, Charles: Lo cómico y la caricatura, Madrid, Antonio Machado, 2001. (1 ${ }^{\mathrm{a}}$ ed. 1988), pp. 81 y 82.

59 En el original, «dit sans dire tout en disant». Ortega, Marie-Linda: "Le (dis)continu á l'oeuvre dans les blagues illustrées du XIX': éclats du rire" Fillière, Carole y Laget, Laurie Anne (coords.): Les relations esthétiques entre ironie et humour en Espagne, XIXe-XXe siècles, Madrid, Casa de Velázquez, 2011, p. 42. 
Figura 13. Francisco Ortego: «ii氵SE ESTRELLARÁ!!!» [La Situación], Gil Blas, 375 (8 de junio de 1871).

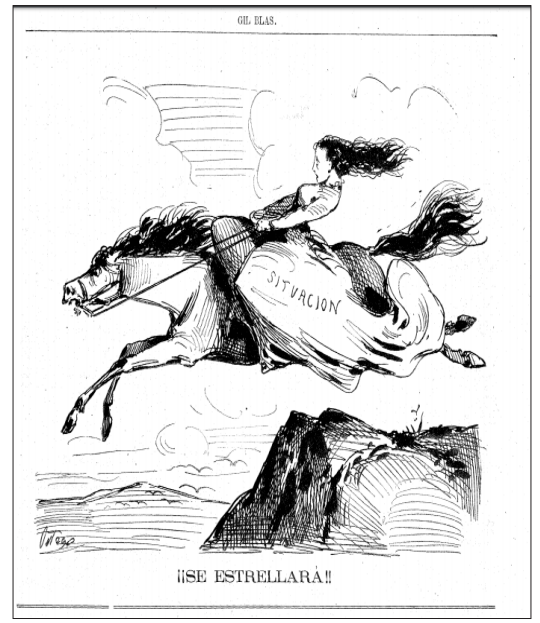

Figura 14. Anónimo: «FOTOGRAFÍA DE LO SOMATENT. Veurem qui s'menjará la poma» [Veremos quién se comerá la manzana], Lo Somatent, 15 (20 de febrero de 1869).

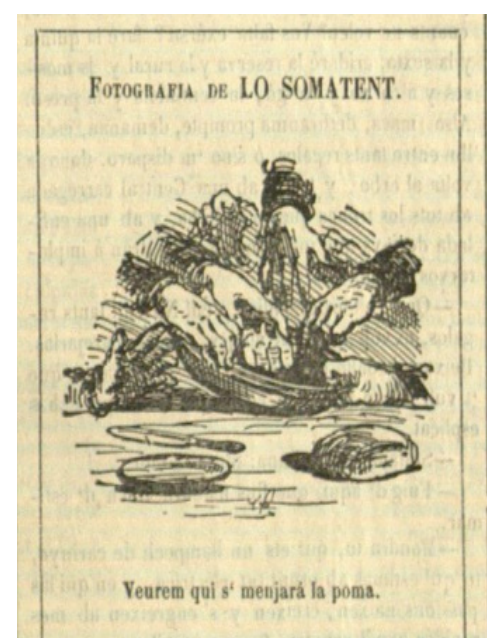

\section{Vicios cardinales}

Para identificar a Juan Moreno Benítez, la primera de las cinco caricaturas en publicarse (figura 1), fue clave su cuello o, lo que es lo mismo, el edificio del asilo de El Pardo, el cual fue fundado por el político el día de San Juan de 1869 para acoger a los menesterosos de las calles de Madrid ${ }^{60}$. De su interior, en el dibujo, surge un dado que reprocha las medidas legislativas que había tomado el gobernador de Madrid contra las casas de juego, junto a los naipes que lucen sobre la empapelada frente de

60 Jiménez-Landi, Antonio: La institución Libre de Enseñanza y su ambiente. Tomo III: "Periodo escolar 18811907”, Madrid, Editorial Complutense, 1996, p. 598. 
Moreno Benítez; es más, su ojo izquierdo parece ser la cabeza de una figura de la sota de la baraja española. El otro ojo ha sido transformado en lámpara (figura 15), vínculo este muy intuitivo, como el que establece Arcimboldo al pintar una flor de campanilla en la oreja de su Primavera (figura 16).

Figura 15. Eduardo Sojo: Sin título, El Caos, 11 (13 de junio de 1870). [Detalle].

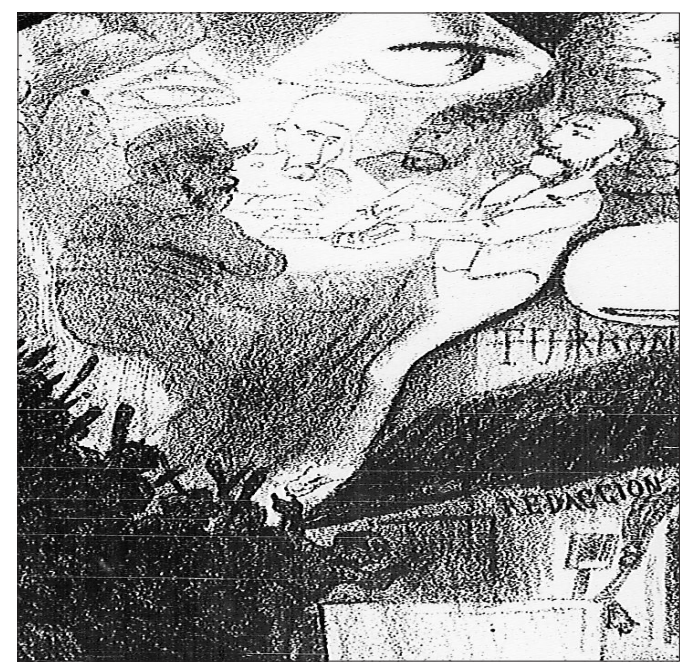

Figura 16. Giuseppe Arcimboldo: La Primavera, 1563. Real Academia de Bellas Artes de San Fernando, Madrid. [Detalle].

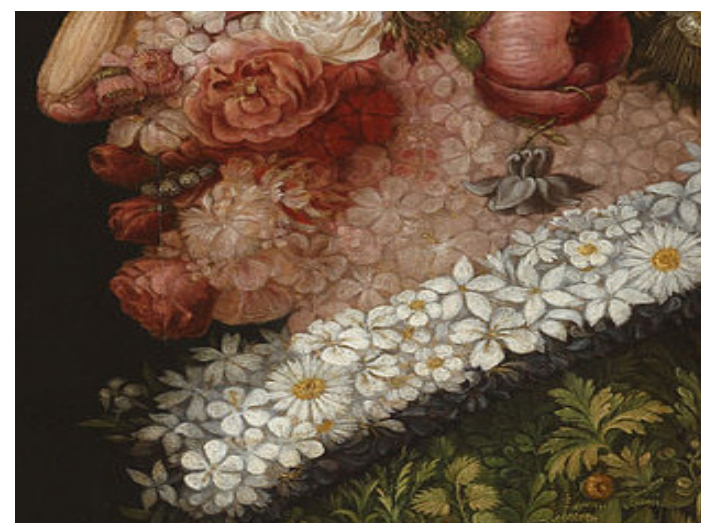

En la escena iluminada por el ojo se encuentra el mismo gobernador, desdoblado, compartiendo mesa con Juan Prim, al fondo, Práxedes Mateo Sagasta, a la derecha de este, y Juan Bautista Topete. En El Caos acompañaban a la viñeta unos versos: «En un circulo........ oficial / y en horas muy sospechosas / peina, talla, [resaltado en el original] y otras cosas, / ? Quien___ Don Fulano de tal», y es que este fulano y los otros tres personajes estuvieron ligados a la partida de la Porra, una organización que se encargaba de mitigar -y el nombre del grupo ya dice mucho de sus medios, lo 
mismo que las porras del siete de bastos/porras de la frente del retratado ${ }^{61}-$, la acción de los periódicos que no encajasen con las ideas de sus miembros y de sus benefactores. Acusaba Sojo de esta manera, en otro de sus periódicos, la vinculación de los políticos con el grupo:

Al escuchar un porrista que á Gil Blas "le da asco" la partida de la Porra, murmuró: "A ver si le hacemos echar las tripas." Por lo cual, yo les digo a todos los que forman esa partida, que ni me dan asco ni me lo han causado nunca. Me parece que no puedo ser mas ministerial ${ }^{62}$.

Fueron desgraciadamente frecuentes las noticias que se hacían eco de palizas a periodistas o destrozos en las redacciones de los periódicos, como sucedió en la de $L a$ Gord $^{63}$, publicación carlista, tal y como se representa en la viñeta: la patilla de Moreno Benítez es una turba armada que se dirige a la redacción de La Gorda, sita en la boca, en la que se distingue un ventanuco carcelario, que es la mosca de la barba del político (figura 17). Con el pájaro muerto que yace sobre la cabeza del gobernador de Madrid y el enrejado de la ventana queda constituida una alusión a la privación de la libertad de prensa: a pesar de las diferencias ideológicas entre los diversos periódicos, la libertad de prensa había de ser cosa común de la profesión, y así lo demuestra el artista, por lo demás, republicano y anticarlista.

Figura 17. Eduardo Sojo: Sin título, El Caos, 11 (13 de junio de 1870). [Detalle].

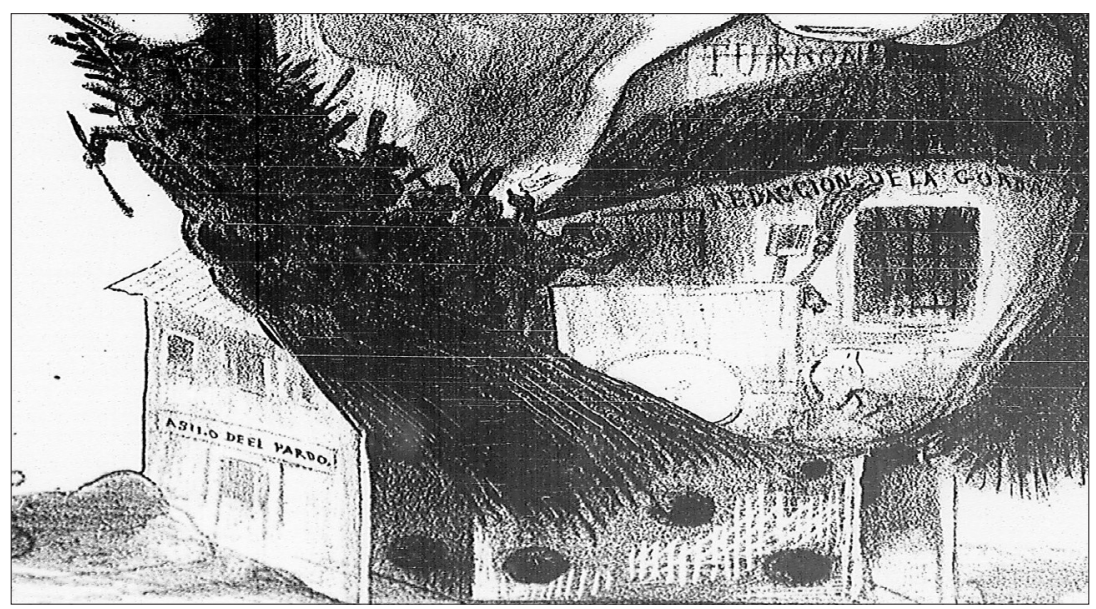

El siguiente blanco fue Antonio de Orleans, más conocido entre los círculos de la sátira como "El rey naranjero" o el "Naranjero", como se denomina en la lámina de Tomás Padró (figura 3). El pseudónimo obedecía al negocio que el duque de Mont-

61 La porra constantemente asociada a las caricaturas de Sagasta se fundamenta en su conexión con la partida de la Porra.

62 Sojo, Eduardo: "Telégramas", en El Noventa y Tres, 3 (5 de diciembre de 1870), p. 4.

63 El Caos daba cuenta, justamente en el número anterior y en el posterior del que corresponde a la caricatura de la que hablamos, del allanamiento de las redacciones de La Gorda - en la que fueron «robados sus papeles a la fuerza»-y de El Papelito. Véanse respectivamente: "Chispazos", en El Caos, 10 (5 de junio de 1870), p. 1 y "Chispazos", en El Caos, 13 (26 de junio de 1870), p. 4. 
pensier había organizado para la venta de las naranjas cultivadas en su propiedad sevillana de la Huerta La Isabela ${ }^{64}$. La presencia de esta fruta en las viñetas sobre el duque era casi obligada; no podía ser de otra forma en las dos caricaturas que presentamos. En la de El Caos (figura 2), dos naranjas componen el moflete y parte de la barbilla, de un modo que recuerda más directamente a Arcimboldo, en cuanto a que se servía usualmente de objetos naturales, aunque verdaderamente no terminan de integrarse en el conjunto. Padró, por su parte, hizo brotar la cabeza del cuñado de Isabel II de una gola de naranjas, como si fuese una flor de azahar. Sojo también había convertido en una flor a su Antonio de Orleans: una rosa envenenada; atendamos, si no, a la serpiente que trepa desde el tallo y termina en el flequillo (figura 18).

Figura 18. Eduardo Sojo: «LA CABEZA CONSPIRANTE», El Caos, 14 (4 de julio de 1870). [Detalle].

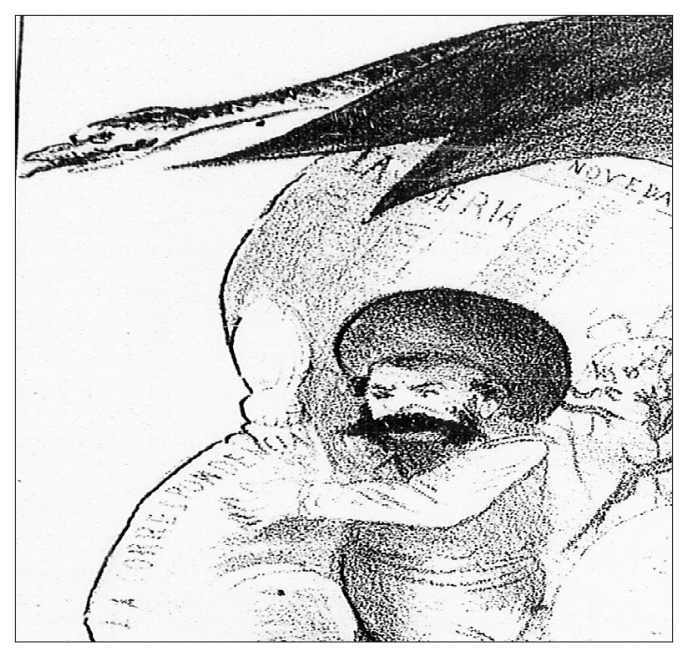

Tampoco faltaban en las caricaturas de este personaje los paraguas; incluso, existía una publicación denominada El paraguas de Montpensier (1870). Hemos de buscar el origen de este atributo en su padre, Luis Felipe de Orleans. Tras la Revolución de julio de 1830, que expulsó a los Borbones del trono de Francia, fue elegido rey. Este monarca constitucional, conocido como el "rey burgués", para reafirmar su cercanía a sus súbditos paseaba por las calles de París caracterizado como un burgués más, sin siquiera escolta, acompañado tan solo de su paraguas ${ }^{65}$. Era habitual este objeto en las caricaturas que se publicaban contra él: de forzosa alusión para el caso son Charles Philippon y Honoré Daumier.

Para la prensa satírica española, Montpensier era digno heredero de este símbolo de cercanía burguesa: el rey naranjero y su esposa, Luisa Fernanda, «totalmente integrados en la ciudad como unos sevillanos más, participaban en sus manifestaciones

64 García Rodríguez, José Carlos: Montpensier. Biografia de una obsesión, Córdoba, Almuzara, 2015, p. 91.

65 Burdiel, Isabel: "Biografía, Biografía de reyes: Isabel II como problema", en Davis, J. Colin y Burdiel, Isabel (eds.): El otro, el mismo. Biografia y autobiografia en Europa (siglos XVII-XX), Valencia, PUV, 2005, p. 146. 
festivas ${ }^{66}$. De su buen hacer se hacían eco los periódicos afines a su persona ${ }^{67}$; era primordial lograr una imagen pública que favoreciese su máxima ambición: ser rey de España. En la caricatura de El Caos el paraguas cubre la cabeza del duque, desempeñando su función original; como defiende Barthes para las cabezas de Arcimboldo, sin desviarse de su uso, «de modo didáctico, como en un libro para niños» ${ }^{68}$. En la otra lámina está plegado y apoyado sobre su oreja (figura 19).

Figura 19. $\mathrm{A}^{\circ} \mathrm{W}^{\circ}$ (Tomás Padró): «RETRATOS ALEGÓRICOS. EL NARANJERO», El Lío, 4 (7 de marzo de 1874). [Detalle].

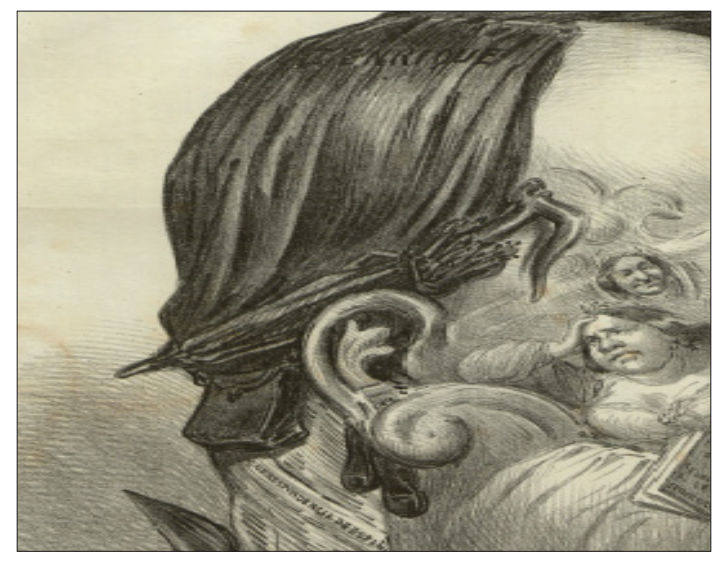

Por su parte, La Flaca publicaba un poema del que tomamos unos versos que dan cuenta de esta migración iconográfica:
Al fin, si proyectos fragua
En lo demócrata toca.
Díganlo su tapaboca,
Sus chanclos y su paraguas.
Con este equipo ligero
Recorrió á París un dia
Su padre, Luis María
Felipe Orleans primero ${ }^{69}$.

Quizás los chanclos del poema sean los que ha situado Sojo debajo de la nariz -y ya podemos imaginar, con un poco de olfato, que el lugar no es casualidad- y Padró, detrás de la oreja también. Por el contrario, el artista catalán había elegido como bigote el cordero de la Orden del Toisón que Isabel II le concedió a su cuñado (figura 20).

\footnotetext{
66 García Rodríguez, José Carlos: Montpensier..., p. 105.

67 García Rodríguez, José Carlos: Montpensier..., p. 144.

68 Barthes, Roland: “Arcimboldo...", p. 139.

69 “Tardis piulasti”, en La Flaca, 37 (6 marzo 1870), p. 3.
} 
Figura 20. $\mathrm{A}^{\circ} \mathrm{W}^{\circ}$ (Tomás Padró): «RETRATOS ALEGÓRICOS. EL NARANJERO», El Lio, 4 (7 de marzo de 1874). [Detalle].

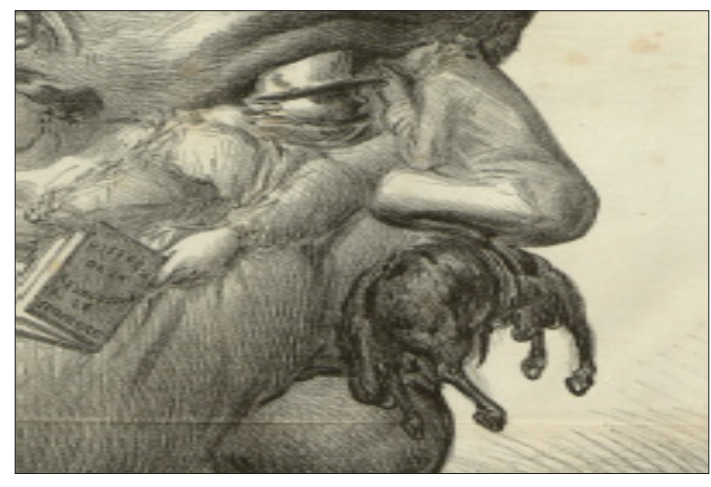

Figura 21. Eduardo Sojo: «LA CABEZA CONSPIRANTE», El Caos, 14 (4 de julio de 1870). [Detalle].

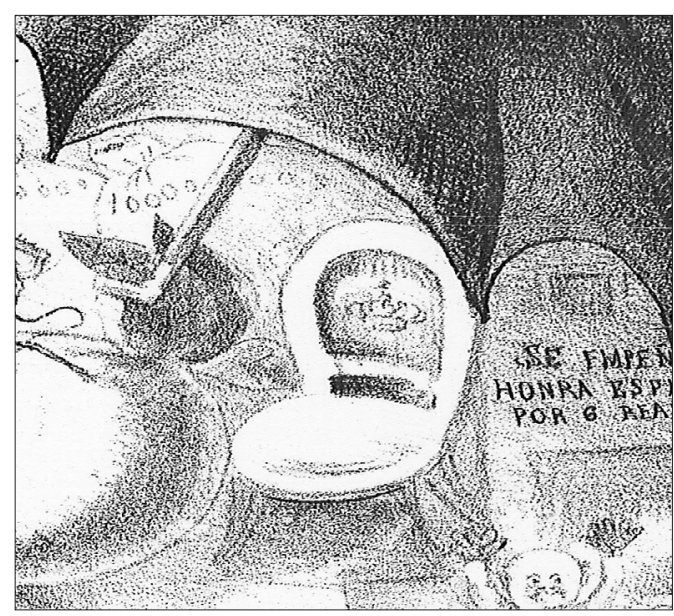

Destacan otras figuras que giran en torno a su gran anhelo. La silla de la sien de la sátira de El Caos es una traducción directa de la palabra al dibujo, pues es, literalmente, el trono vacío pretendido por el duque de Montpensier (figura 21). Es decir, parte de la comprensión de la iconografía de las caricaturas reside en la reutilización de expresiones comunes:

La lengua proporciona de forma discreta una referencia sensata a esas pinturas en apariencia fantasiosas [...] El arte de Arcimboldo no es extravagante; se mantiene siempre en los linderos del sentido común, al borde del proverbio; sabía que los príncipes, que eran los destinatarios de esas diversiones, tenían que asombrarse pero al mismo tiempo reconocer el juego; ésa es la razón de que lo maravilloso aparezca enraizado en frases usuales $[\ldots]^{70}$.

70 Barthes, Roland: “Arcimboldo...”, pp. 136 y 137. 
Existían otras metáforas de construcción semejante: el dibujo de una cuba de madera que correspondía a la isla de Cuba -la cual, recordemos, seguía siendo colonia española hasta 1898- o de una caja de turrón (figura 15), ya que así era como se denominaba al beneficio personal que de sus cargos públicos obtenían determinadas personalidades como Juan Moreno Benítez, pues puede verse una caja de turrón en su caricatura, justo debajo de su nariz -si bien Juan Prim o Sagasta fueron los más acusados de este abuso, según las caricaturas del Sexenio-.

En la segunda lámina, la publicada en El Lío, hay una corona grabada sobre la frente del duque de Montpensier. En uno de sus medallones se distingue la cara de María Cristina de Borbón (figura 19). Madre de Isabel II y de Luisa Fernanda, auspició la candidatura de su yerno francés, pues era el marido de su hija preferida y opositor de la reina, su hija despreciada, al menos hasta que tuvo acceso al trono, pues aún queda el más desgraciado comentario al deseo de reinar.

En medio de la campaña de Montpensier por el trono de España, su primo Enrique de Borbón, duque de Sevilla, publicó una serie de escritos ofensivos contra él. El último fue una furibunda hoja volante titulada $A$ los montpensieristas que condujo a Orleans a desafiarle. El denominado Duelo de Carabanchel tuvo lugar el 12 de marzo de 1870 y el duque de Sevilla resultó muerto. Tras el duelo, fue condenado a un mes de destierro a más de diez leguas de Madrid y a indemnizar a la familia de su primo ${ }^{71}$. Pocos meses después del triste acontecimiento, Eduardo Sojo, directo y brutal, dibujaba en su viñeta el esqueleto del fallecido sosteniendo dos pistolas, atragantándose en el cuello del retratado (figura 22). Junto al difunto, dos lápidas en las que se adivina «Aquí yace Enrique» y «Aquí yace Isabel»: el dibujante madrileño le atribuye una supuesta muerte de su cuñada para dejar patente la falta de escrúpulos del duque. Mucho más poético es el yacente que peina la cabeza del Antonio de Orleans de Padró (figura 23).

Figura 22. Eduardo Sojo: «LA CABEZA CONSPIRANTE», El Caos, 14 (4 de julio de 1870). [Detalle].

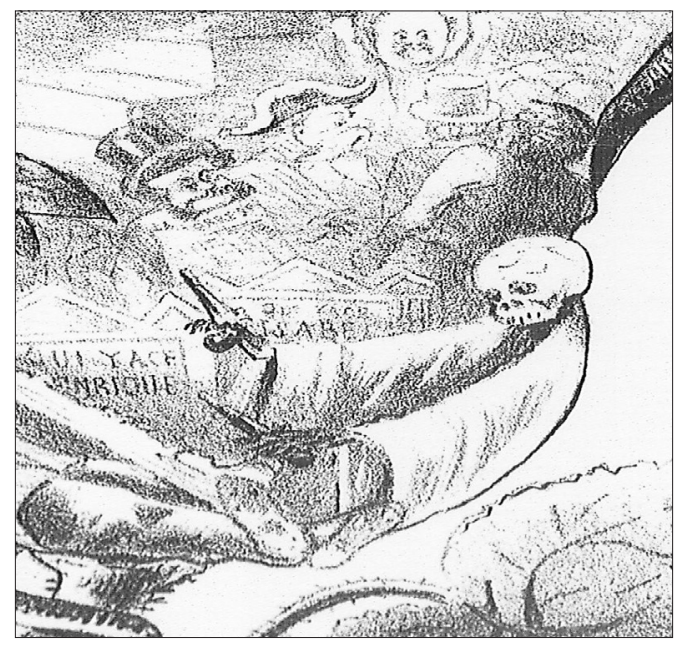

71 García Rodríguez, José Carlos: Montpensier..., p. 229. 
Figura 23. $\mathrm{A}^{\circ} \mathrm{W}^{\mathrm{o}}$ (Tomás Padró): «RETRATOS ALEGÓRICOS. EL NARANJERO», El Lio, 4 (7 de marzo de 1874). [Detalle].

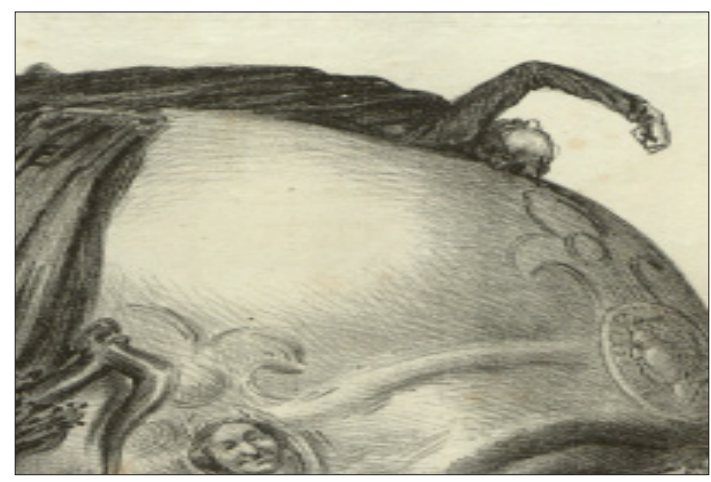

Por último, diferenciemos los ojos de cada retrato. En la viñeta madrileña el ojo no es otro que Juan Bautista Topete - con el que hemos coincidido para el retrato de Moreno Benítez-, el que fuera uno de los máximos apoyos de la fallida candidatura del retratado. El almirante Topete, vestido de marinero, se aferra a la nariz de Antonio de Orleans, cubierta por otro de los órganos que favorecieron al pretendiente Montpensier primero y la restauración borbónica después; el periódico La Correspondencia de España ${ }^{72}$, igualmente presente en la nuca del retrato alegórico de Padró.

Volviendo a los ojos de Montpensier, en el dibujo de El Lio, la cabecita que asoma por la cuenca es la de Alfonso, el hijo en el que había abdicado Isabel II, quien, como moflete de su rival, reposa melancólica, seguramente por su decisión de renunciar al trono. A pesar de sus dieciséis años de edad, el futuro Alfonso XII era caracterizado poco antes de su ascenso al trono -que se produciría en diciembre del mismo año de 1874 en que se imprimía esta caricatura- como un niño. Pues bien, una vez que Montpensier hubo perdido toda posibilidad de convertirse en rey tras la muerte de Enrique de Borbón, favoreció la candidatura de su sobrino calculando que sería la posición más cercana a la corona a la que aspirar y, más aún, con el posterior matrimonio de su hija María de las Mercedes con Alfonso, aseguraba la presencia de la familia de Orleans en el trono. Ya publicaba Gil Blas una caricatura en 1871 que representa a Montpensier como ángel custodio del joven pretendiente (figura 24) y, en el mismo número, un artículo del que extraemos un significativo fragmento:

D. Antonio entrega á su hija y tantos millones. Doña Isabel da al hijo de sus entrañas y cuatro varas de legitimidad [...] D. Alfonso de Borbon: Rey.- Doña Isabel de Borbon: Reina.- D. Antonio de Borbon: Regente.-Otra doña Isabel de Borbon: Papisa.- D. Francisco de Borbon: Doncella... y así siguen todos los Borbones ${ }^{73}$.

\footnotetext{
72 Laguna Platero, Antonio; Martínez Gallego, Francesc Andreu: "Pioneros de la información española", en Revista internacional de Historia de la Comunicación, I, 4 (2015), p. 13.

73 Matoses, Manuel: “Conjunción”, en Gil Blas, 392 (6 de agosto de 1871), p. 2.
} 
Figura 24. Francisco Ortego: Sin título, Gil Blas, 392 (6 de agosto de 1871).

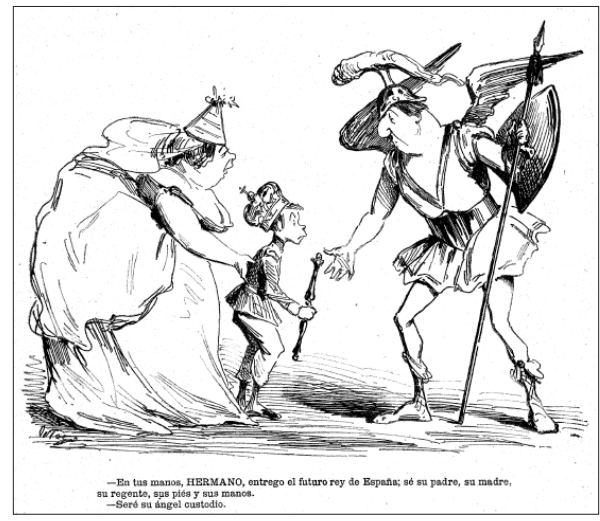

El siguiente turno fue el de Francisco Savalls, el mismo que había amenazado al director del semanario satírico barcelonés La Correspondencia del Diablo, a causa de una caricatura en la que Carlos VII y su esposa, Margarita de Borbón-Parma, aparecían «nada menos que en paños menores» ${ }^{74}$, era protagonista, dos años después, de su propia caricatura (figura 4). Y así como sobre la cabeza de Moreno Benítez había un pájaro muerto y sobre la de Montpensier, Enrique de Borbón, cae difunta por encima de la del militar carlista la personificación de la Libertad. Esta posición de los cadáveres no tiene por qué ser azarosa, sino alusiva al peso que hubieron de soportar estos tres personajes de por vida sobre sus conciencias, esto es, sobre sus cabezas, tomando así el sentido literal la expresión como hiciera Arcimboldo y como hiciera Cyrano de Bergerac, cuyo procedimiento -cuenta Barthes-consistía en «tomar una metáfora del lenguaje, lo más trivial posible, y explotar hasta el infinito su sentido literal» $\rangle^{75}$.

La Libertad de la cabeza de Savalls es además la boina con la que se identificaba metonímicamente a los $\operatorname{carlistas}^{76} \mathrm{y}$, por la fecha del dibujo, también a la tercera de las Guerras Carlistas. Esta había comenzado ya en el año 1872, alargándose hasta principios de 1876. Las representaciones de una libertad como una mujer sufriente fueron más que habituales en las caricaturas de los periódicos del último tercio de este siglo XIX. Se trata de una imagen "solemne”, como designa Maestrojuán a figuras como España o la República, normalmente presentadas «idealizadas y sin intención humorística $\rangle^{77}$, tal y como lo evidencia Padró.

La Libertad muerta o la ausencia de libertad, indicada en la lámina con la cadena que forma la corbata del personaje (figura 24), componen una más de las críticas a los principios carlistas ya que, frente al lema de "Libertad, Igualdad y Fraternidad" el carlismo enarbolaba el de "Dios, Patria y Rey" - escrito en la camisa de Savalls (figura 25)-, ridiculizado y juzgado como signo de la tradición española más rancia ${ }^{78}$.

74 “Europa", en La Correspondencia del Diablo, 9 (27 de octubre de 1872), p. 1.

75 Barthes, Roland: “Arcimboldo...", p. 138.

76 A colación del gorro frigio como elemento identificador de la república, Francisco Javier Maestrojuán destaca la fácil interpretación que llevan consigo los tocados, mencionando la función metonímica de la boina carlista. Véase Maestrojuán Catalán, Francisco Javier: "El lenguaje en imágenes: 1873, España y la República. Un coqueteo a través de la prensa satírica", en Anthropos, huellas del conocimiento, 223 (2009), p. 189.

77 Maestrojuán Catalán, Francisco Javier: "El lenguaje...”, p. 190.

78 «...] la tradición es bella como un romance y sagrada como un rito» son las románticas palabras con las que, desde la cara opuesta del conflicto, el Marqués de Bradomín -el refinado caballero carlista de Valle-Inclán- 
Figura 25. $\mathrm{A}^{\circ} \mathrm{W}^{\circ}$ (Tomás Padró): «RETRATOS ALEGÓRICOS. SAVALLS», El Lio, 1 (7 de febrero de 1874).

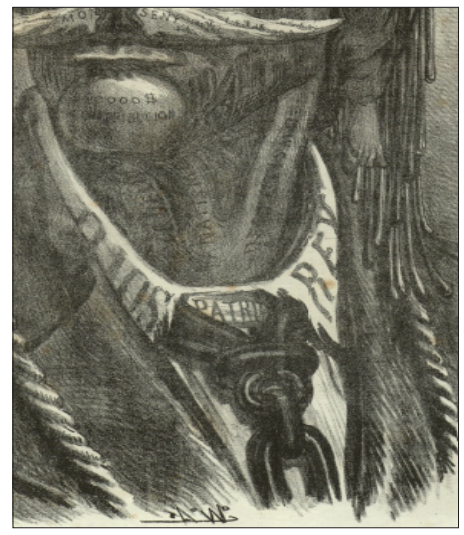

Así pues, en las caricaturas en torno al carlismo no podían faltar las alusiones al clero por ser considerado como uno de los principales culpables de los males que arrastraba España y como vestigio del Antiguo Régimen. El proceder asimilado por todos los caricaturistas de entonces era mostrar a los miembros del clero con una feliz barriga y la alegre y placentera expresión de quien puede gozar de los beneficios del vino y de la carne. Es muy significativo el lugar que ocupan los eclesiásticos en las dos viñetas. Además, contienen algunas peculiaridades comunes a aquella caricatura de Isabel II que había circulado por el país en tiempos de la Gloriosa (figura 11). En ella, el Papa - caracterizado con la triple tiara papal- conforma la nariz de la reina y extiende sus brazos en cruz para descorrer su pelo-cortinaje (figura 27). Lo hace ocupando su frente y, por tanto, su pensamiento, al tiempo que le mantiene la boca cerrada con los pies. A su vez, los ojos y los oídos de la de los tristes destinos son miembros del clero. Es decir, la Iglesia controla todas sus facultades.

Figura 26. $\mathrm{A}^{\circ} \mathrm{W}^{\mathrm{o}}$ (Tomás Padró): «RETRATOS ALEGÓRICOS. SAVALLS», El Lio, 1 (7 de febrero de 1874). [Detalle].

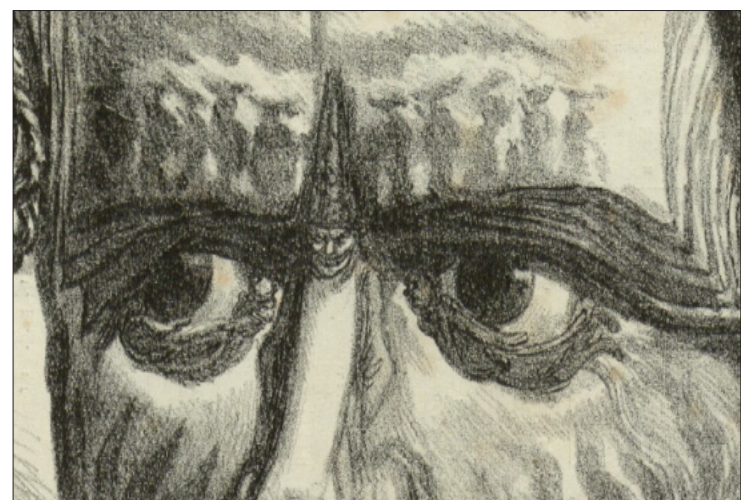

respondía a Sor Simona, quien le increpaba por las tropelías cometidas por los soldados que le acompañaban en una de las campañas de la tercera guerra carlista. Véase Valle-Inclán, Ramón María: Sonata de Invierno, Madrid, Espasa Calpe, 1981. (1 ${ }^{\mathrm{a}}$ ed. 1944), p. 150. 
Figura 27. Caricatura de Isabel II, ca. 1868. [Detalle].

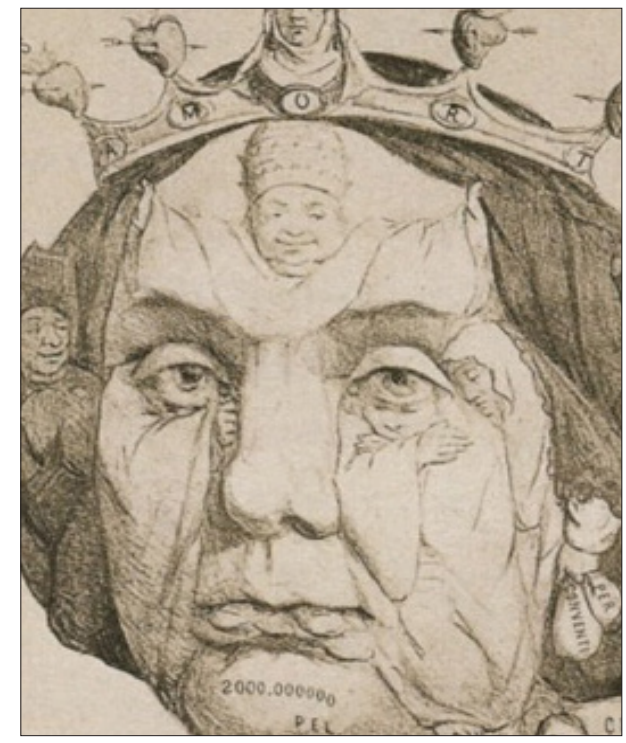

Ocurre algo semejante en la cara de Francisco Savalls, pero esta vez la nariz es un hombre de expresión demoníaca vestido con un sambenito (figura 26) que insinúa la Inquisición sugiriendo, en consecuencia, el cariz reaccionario de los valores carlistas. La sencilla señal que constituye el sambenito indica la asimilación de la asociación entre Inquisición y carlismo en el imaginario colectivo, confirmada con ejemplos de caricaturas anteriores en las que los instrumentos de tortura empleados por la antigua institución no faltan (figuras 28 y 29).

Figura 28. Anónimo: «Las numerosas huestes del Terso toman marcialmente posesión del PAIS CONQUISTADO», El Guirigay del 69, 7 (1869). [Detalle en el que se distingue «Santo Oficio» en el estandarte que portan los personajes de la parte derecha de la imagen].

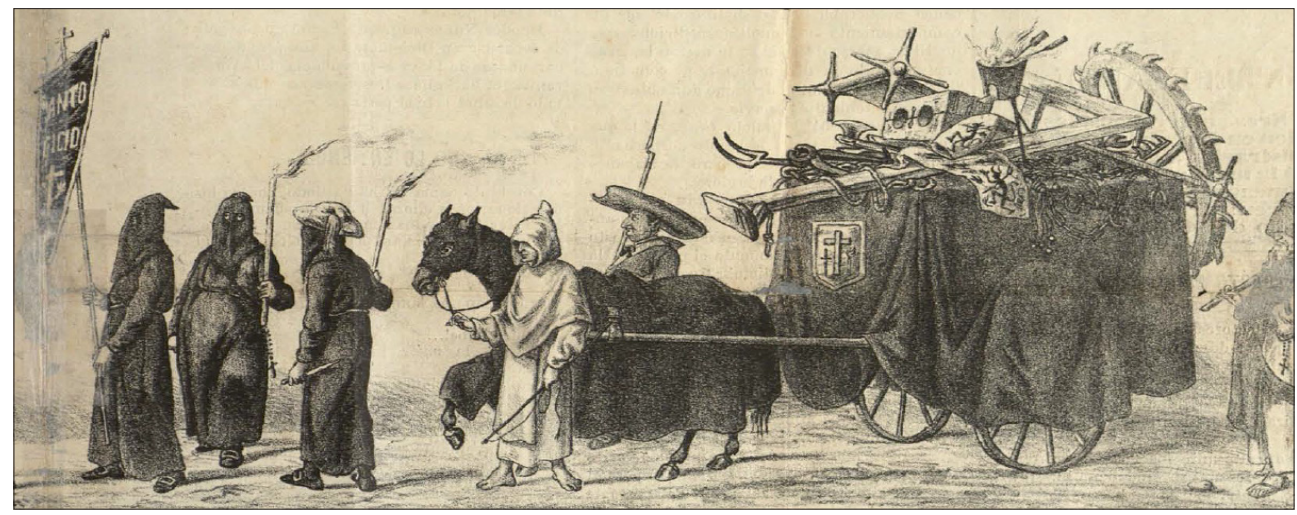


Figura 29. Anónimo: «LA INQUISICIÓN POR DENTRO EN EL SIGLO DE LAS LUCES», La Carcajada, 20 (22 de junio de1872).

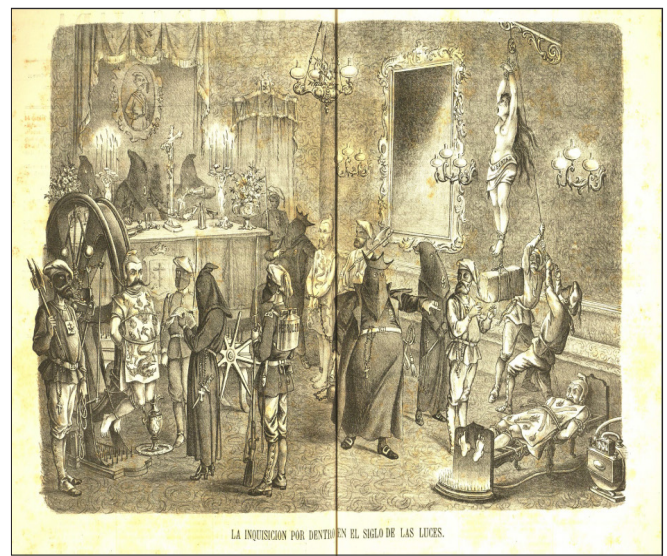

De la espalda del personaje con sambenito, a la manera de la cruz que ocupaba la cara de la Isabel II, parten las dos cejas del carlista, que ahora son terribles alas en las que están posados, como cuervos, la sombra de otros clérigos. Las cejas son también los cantos del libro que forma la frente y la mente del retratado, en el que se leen los crímenes de guerra de Savalls: "Fusilamientos de Berga/ Saqueo de Igualada/ Incendio de Tortella".

Para el rey de los carlistas (figura 5), Padró escogió ubicar el elemento religioso en sus tristísimos ojos; las cabezas de dos curas provistos de equipamiento militar porque también combatían-, y en el bigote. Este lo forman dos eclesiásticos que leen afanosamente un libro - ¿la Biblia? -, que es el labio superior. Ambos están tumbados sobre el prominente labio inferior de Su Majestad Tersa -como solía llamársele entre sus detractores ${ }^{79}$ - que es, al tiempo, el fuego que le sale del corazón, ahora en la barbilla. Este desubicado órgano es bombeado gracias, no a la carótida y a la aorta, sino a la "crueldad" y la "ambición", según está escrito en el dibujo. Así, el corazón de Carlos VII, movido por la crueldad y la ambición, hace que salgan de sus labios incendiarias palabras de "vanidad", tal y como indica la inscripción, sobre las que se apoya el clero (figura 30).

La efigie del Terso está además coronada por un tigre alusivo al general carlista Ramón Cabrera, apodado por los liberales como "Tigre del Maestrazgo" para resaltar la crueldad y virulencia del militar. Otra vez nos hallamos ante una trasposición directa de la palabra al dibujo.

Debido al conflicto armado, la presencia de la muerte en ambas caricaturas es axiomática, ya sea a través de huesos o de cadáveres. Numerosas calaveras le taponan la oreja y son contenidas por el lóbulo, convertido en una mortífera serpiente -en cuya piel se forma la palabra "guerra civil" (figura 31)- como la que reptaba por la cabeza de Antonio de Orleans.

79 Gordillo Courcières cita a Antonio Guzmán de León, quien atribuyó el origen de este epíteto a una malintencionada aclaración de un artículo del periódico carlista La Esperanza en el que se elogiaba lo terso de las costumbres de la facción carlista de los Borbones, frente a la otra. Véase Gordillo Courcières, José Luis: Todo el siglo es carnaval, Madrid, El Museo Universal, 1993, p. 122. 
Figura $30 . \mathrm{A}^{\circ} \mathrm{W}^{\mathrm{o}}$ (Tomás Padró): «RETRATOS ALEGÓRICOS. S. M. TERSA», El Lío, 7 (18 de junio de 1874). [Detalle].

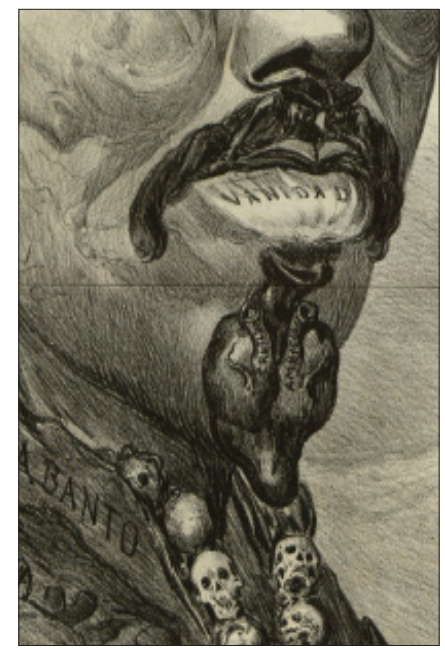

Figura 31. $\mathrm{A}^{\circ} \mathrm{W}^{\mathrm{o}}$ (Tomás Padró): «RETRATOS ALEGÓRICOS. S. M. TERSA», El Lío, 7 (18 de junio de 1874). [Detalle].

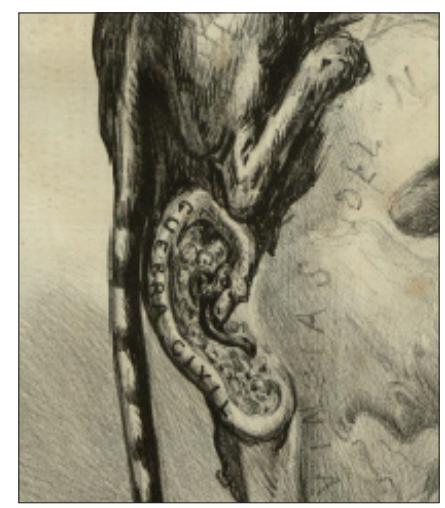

Y acudimos otra vez a las estampas italianas de Isabel II para equiparar el modo en que los muertos descansan sobre las clavículas de los dos borbones, y los eslabones de la fúnebre cadena de una y otro (figuras 32 y 33), con la salvedad de que de la cadena del pretendiente al trono cuelga un burro: la Orden del Toisón de Oro era así rebautizada con un símbolo claro de la ignorancia que se le achacaba al carlismo, junto al retroceso, incorporado en la viñeta gracias al cangrejo -sobre mencionar su manera de desplazarse- del escapulario del pecho del Terso, debajo del cual se lee «Liberal detente que la estupidez y el retroceso van conmigo». Se trata de una paráfrasis del denominado detente: una imagen del Sagrado Corazón de Jesús que se empleaba a modo de salvaguarda. Su nombre proviene de la exhortación -igualmente deformada en la lámina- «Detente, el Corazón de Jesús está conmigo» ${ }^{80}$.

80 Herradón Figueroa, María Antonia: "Reinaré en España. La devoción al Sagrado Corazón de Jesús” [en línea], en Revista de Dialectología y Tradiciones Populares, LXIV, 2 (2009), pp. 206-211. [Consulta: 18 de mayo de 
Figura 32. $\mathrm{A}^{\circ} \mathrm{W}^{\mathrm{o}}$ (Tomás Padró): «RETRATOS ALEGÓRICOS. S. M. TERSA», El Lío, 7 (18 de junio de 1874). [Detalle].

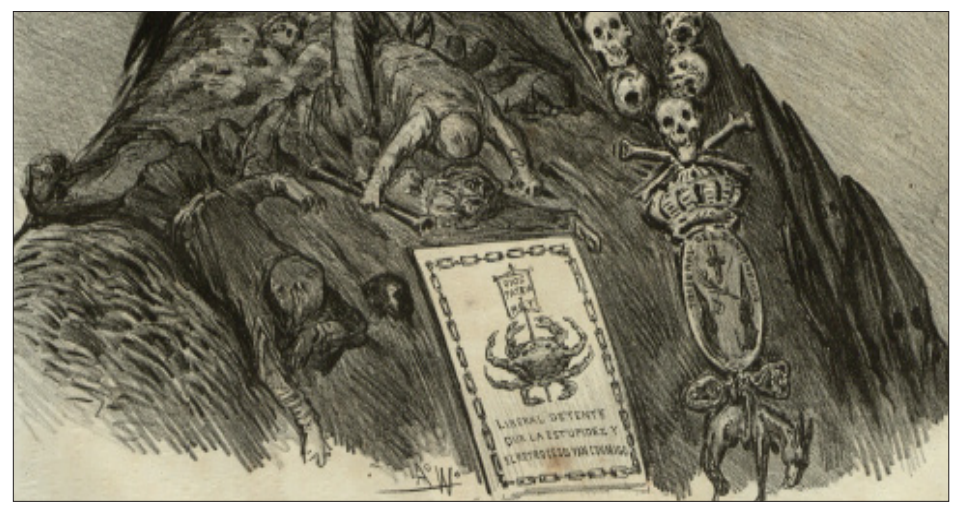

Figura 33. Caricatura de Isabel II, ca. 1868. [Detalle].

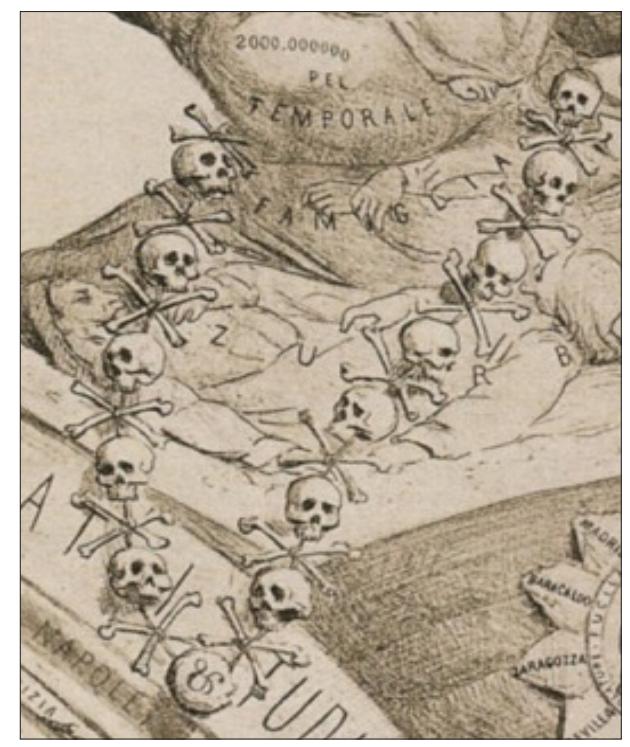

En aquella primavera de 1874 en la que se difundían las caricaturas de Padró, la república cumplía un año de vigencia y el apremio para poner fin al gobierno era cada vez mayor por parte de sus oponentes, que aún guardaban fidelidad a sus pretendientes al trono: eran los carlistas y los alfonsinos. Ambos grupos quedaron representados en los retratos alegóricos de Padró: reunió en tres personajes a los enemigos de la república y de la libertad, igualadas y aunadas en dibujos como el que hizo para La Flaca; un acercamiento al celebérrimo óleo de Delacroix (figura 34). 
Figura 34. $\mathrm{A}^{\circ} \mathrm{W}^{\mathrm{o}}$ (Tomás Padró): « Solamente marchando unidos, podremos pasearla triunfante», La Flaca, 1 (2 de junio de 1873).

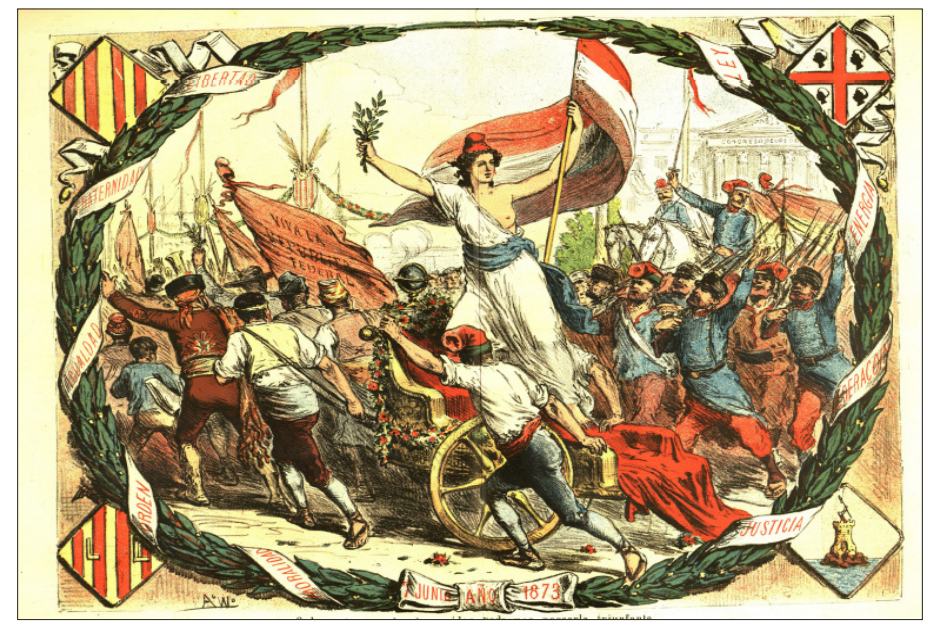

\section{Juegos de la deformación}

Tras conocer con más profundidad las láminas, encontramos que existen bastantes puntos de conexión con las obras del pintor del Cinquecento, en lo que a recursos retóricos se refiere. Pero existen otros que deberíamos tener en cuenta.

En suma, la pintura de Arcimboldo es móvil: en virtud de su propio proyecto, dicta al lector la obligación de acercarse o alejarse, le asegura que en ese movimiento no perderá ni un ápice de sentido y que seguirá estando en una relación viva con la imagen ${ }^{81}$.

A este mismo movimiento es al que nos invitan nuestros dibujantes. Tanto es así que los retratos de Tomás Padró -más notoriamente que su colega madrileño-vistos en conjunto ni siquiera parecen caricaturas, entendidas como la deformación o exageración de las facciones de los personajes. En esta característica, en la apariencia no-deformada, es en la que reside la clave de una diferencia principal con respecto al pintor del Giuseppe Arcimboldo.

Recapitulemos sobre proceder del pintor milanés como obrero del lenguaje, obviando su faceta poética: componía sus óleos a partir de elementos más pequeños, siguiendo una progresión pareja a la de la lengua: fonemas-palabras-frases-discurso. Es el espectador-lector quien ha de encargarse de descomponer, dado el carácter móvil de sus pinturas, las cabezas. Y lo mismo pudo hacer el público que accedió a las cinco láminas españolas. Lo cierto es que, hasta ahora, nos hemos referido a ellos en términos relacionados con la "composición" y no hemos sido por ello estrictamente correctos.

81 Barthes, Roland: “Arcimboldo...", pp. 145 y 146. 
Muy a menudo, los efectos que en nosotros promueve el arte de Arcimboldo son repulsivos [...] Lo que condena hasta tal punto a las figuras de Arcimboldo a producir tal efecto de malestar es precisamente el hecho de que estén "compuestas" [...] Es este mismo procedimiento de la "composición" lo que [...] dificulta el surgimiento unitario de la forma ${ }^{82}$.

A pesar de la repulsa y de la monstruosidad aparentes de los cuadros del artífice italiano, los retratados son elogiados simbólicamente. Por el contrario, las caricaturas que, como tal, satirizan a los personajes que muestran, no tienen aspecto tan desagradable, como hemos adelantado. Esto ocurre por la sencilla razón de que han sido concebidas a partir de una imagen previa, de un retrato. Aún la más monstruosa, la caricatura del duque de Montpensier de Eduardo Sojo, posee una particularidad que apoya lo dicho: su nariz es una nariz. Las formas con sentido independiente que en todas las viñetas distinguimos han sido adaptadas a las caras de los personajes. Con lo cual, la caricatura viene dada no por la exageración, o la $\operatorname{carga}^{83}$, de los rasgos -como se entiende tradicionalmente el género de la caricatura- sino por el efecto producido por los dibujantes al sustituir las partes de la cara y de la cabeza por otros elementos. Mientras el pintor lombardo partía de objetos separados que ordenaba para conformar una cabeza, Sojo y Padró lo hicieron desde el orden, de lo que resulta que estas cabezas no son compuestas sino descompuestas; y he aquí la aclaración del título de este artículo.

Pese a la diferencia de construcción, uno y otros artistas lograron, por distintas vías, llegar a crear imágenes grotescas, entendiendo esta categoría como aquella que se obtiene de la mezcla de elementos y, por lo tanto, de su desubicación natural en beneficio de un sentido otro que resulta igualmente convincente. Todos ellos idearon efigies convincentes por medio de rasgos que pertenecen a otros ámbitos de la realidad. No obstante, gracias a su manera de concebir sus cabezas, Arcimboldo pudo ir más allá. Consiguió a la vez un retrato y una naturaleza muerta ${ }^{84} \mathrm{y}$, más aún, podía volver a combinar sus elementos una y otra vez para realizar otras obras compues$\operatorname{tas}^{85}$ totalmente nuevas.

Aun sabiendo lo anterior, seguimos sin poder afirmar que los dos caricaturistas hubiesen tomado como modelo inmediato los óleos de Arcimboldo; pero poca importancia tiene, pues habría sido suficiente con que accediesen a cualquier representación compuesta y la tomasen como ejemplo para declararlos continuadores directos del pintor lombardo, ya que contaban con la ventaja de ser caricaturistas.

La caricatura, por naturaleza, necesita figuras retóricas y, por lo tanto, los dos dibujantes han creado sus cabezas utilizando, como lo hacían en el resto de viñetas, su

82 Barthes, Roland: “Arcimboldo...", pp. 148 y 150.

83 «Acudiendo al significado de caricare, cargar en italiano, la caricatura puede ser definida como la exageración del retrato». Véase Álvarez Junco, Manuel: El humor gráfico y su mecanismo transgresor, Madrid, A. Machado Libros, 2016, p. 77.

84 «...] Tampoco la decoración elaborada de una mesa, que combina todo tipo de vegetales, frutas y flores, se percibe como grotesca. Cuando estos elementos componen una imagen que resulta tan convincente como retrato y como naturaleza muerta [...] se convierten en grotescos». Véase Connelly, Frances S.: Lo grotesco en el arte y la cultura occidentales, Madrid, Machado Libros, 2015, p. 34.

85 Barthes, Roland: “Arcimboldo...”, p. 145. 
arsenal. Cierto es sus discursos están articulados a través de metáforas "prefabricadas". No obstante, su interés por ubicarlas, en bastantes casos, en posiciones concretas de las cabezas, por adaptar eficazmente los objetos y, en fin, por articular este tipo de obras, denotan un esfuerzo en su labor como caricaturistas que va más allá del afianzamiento de un público comprador y, por lo tanto, se consolidaría la posibilidad de motivaciones artísticamente reivindicativas a través y en virtud de la caricatura.

En un oficio que demandaba entregas cada semana -y era habitual que colaborasen en varias publicaciones-, láminas como estas cinco hablan de mucho más que de un simple dibujo malintencionado. Y si, en efecto, las citas y las versiones de "grandes obras" fueron abundantes no confieren a las viñetas que los poseen mayor valor artístico, pues el género de la caricatura posee la suficiente riqueza como para que la referencia sea un recurso más. Quiere decirse que, aun a pesar de no conocer el acceso de Sojo y Padró a Arcimboldo -y con ello de la difusión de la obra del pintor milanés-, sí que podamos intuir una cierta influencia por su modo característico de pintar, este vínculo no tiene por qué predisponer al espectador a una mirada más favorable. Efectivamente, es una manera muy llamativa de retrato, pero la intención última de llevar a cabo una lectura barthesiana es remarcar la rotunda potencia que le es propia a la caricatura.

\section{Referencias bibliográficas}

Alonso, Cecilio: "Épica y sátira en los dibujos de Francisco Ortego en torno a la Guerra de África (1859-1860)", en Borja Rodríguez y Raquel Gutiérrez (coords.): Literatura ilustrada decimonónica: 57 perspectivas, Santander, Publican, 2011, pp. 13-40.

Álvarez Junco, Manuel: El humor gráfico y su mecanismo transgresor, Madrid, Antonio Machado, 2016.

Barthes, Roland: Lo obvio y lo obtuso. Imágenes, textos, voces, Barcelona, Paidós, 1992 (1 ${ }^{\mathrm{a}}$ ed. 1982).

Baudelaire, Charles: Lo cómico y la caricatura, Madrid, Antonio Machado, 2001. (1 ${ }^{\mathrm{a}} \mathrm{ed}$. 1988).

Bonet Correa, Antonio (et al.): Real Academia de San Fernando. Guía del Museo, Madrid, Real Academia de Bellas Artes de San Fernando, 2012.

Bori, Salvador: Tres maestros del lápiz. Padró, Planas y Pellicer, Ediciones Librería Milla, 1945.

Bozal, Valeriano: "El grabado popular en el siglo XIX", en Juan Carrete, Jesusa Vega, Valeriano Bozal y Francesc Fontbona: El grabado en España. Siglos XIX y XX, Madrid, Espasa Calpe, 1988, vol. XXXII de Summa Artis, pp. 245-426.

Burdiel, Isabel (ed.): Los Borbones en pelota, Zaragoza, Institución Fernando el Católico, 2012.

Burdiel, Isabel: "Biografía, Biografía de reyes: Isabel II como problema", en J. Colin Davis e Isabel Burdiel (eds.): El otro, el mismo. Biografía y autobiografía en Europa (siglos XVII-XX), Valencia, PUV, 2005, pp. 141-176.

Casas Delgado, Inmaculada: Romances con acento andaluz. El éxito de la prensa popular (1750-1850), Sevilla, Fundación Pública Andaluza Centro de Estudios Andaluces, 2012.

Cendán Pasos, Fernando: Historia del derecho español de prensa e imprenta (1502-1966), Madrid, Editora Nacional, 1974.

Connelly, Frances S.: Lo grotesco en el arte y la cultura occidentales, Madrid, Antonio Machado, 2015. 
Díaz Marcos, Ana María: La edad de seda: representaciones de la moda en la literatura española (1768-1926), Cádiz, Universidad de Cádiz, 2006.

Fernández Sarasola, Ignacio: La legislación sobre historieta en España, Sevilla, ACyT, 2014.

Fontanals i del Castillo, Joaquim: Recuerdo al artista Tomás Padró, Tribútanle otros de los admiradores de su ingenio, Barcelona, Tipografía Litográfica C. Verdaguer, 1877.

García Rodríguez, José Carlos: Montpensier. Biografía de una obsesión, Córdoba, Almuzara, 2015.

Gombrich, Ernst Hans: Meditaciones sobre un caballo de juguete, Barcelona, Seix Barral, 1968.

Gómez Aparicio, Pedro: Historia del periodismo español. De la Revolución de Septiembre al desastre colonial, Madrid, Editora Nacional, 1971.

Gordillo Courcières, José Luis: Todo el siglo es carnaval, Madrid, El Museo Universal, 1993.

Herradón Figueroa, María Antonia: „Reinaré en España. La devoción al Sagrado Corazón de Jesús“ [en línea], en Revista de Dialectología y Tradiciones Populares, LXIV, 2 (2009), pp. 193-218. [Consulta: 18 de mayo de 2017]. Disponible en: http://rdtp.revistas.csic.es/ index.php/rdtp/article/view/86/87.

Hulten, Pontus (ed.): The Arcimboldo Effect. [Cat. exp.]. Venecia, Palazzo Grassi, 1987.

Jiménez-Landi, Antonio: La institución Libre de Enseñanza y su ambiente. Tomo III: "Período escolar 1881-1907”, Madrid, Editorial Complutense, 1996.

Laguna Platero, Antonio; Martínez Gallego, Francesc Andreu: "Imaginarios femeninos a través de la prensa satírica: de Gil Blas a Don Quijote", en Revista de la Asociación Española de Investigación de la Comunicación, II, 3 (2015), pp. 47-61.

— "Pioneros de la información española", en Revista internacional de Historia de la Comunicación, I, 4 (2015), pp. 01-21.

— "Eduardo Sojo, el Quijote de la caricatura" [en línea], en IC-Revista Cientifica de Información y Comunicación, 12 (2015), pp. 111-134. [Consulta: 2 de febrero de 2017]. Disponible en: https://idus.us.es/xmlui/handle/11441/33051.

Laguna Platero, Antonio: "El poder de la imagen y la imagen del poder" [en línea], en IC Revista Científica de Información y Comunicación, 1 (2003), pp. 111-129 [Consulta: 19 de enero de 2017]. Disponible en: https://idus.us.es/xmlui/handle/11441/18275.

— "El espejo de la revolución burguesa", en Manuel Chust (ed.): De la cuestión señorial a la cuestión social, Valencia, PUV, 2002, pp. 123-136.

Maestrojuán Catalán, Francisco Javier: "El lenguaje en imágenes: 1873, España y la República. Un coqueteo a través de la prensa satírica", en Anthropos, huellas del conocimiento, 223 (2009), pp. 185-198.

Méndez Rutllán, María: "Prensa madrileña de la revolución, 1868-1874. Eduardo Sojo caricaturista político", en Villa de Madrid, 60 (1878), pp. 63-70.

Mestres, Apeles: "Pellicer", en La Lectura, 1 (1902), p. 590.

Orcajo, Javier: "La prensa satírico-gráfica en las otras abdicaciones borbónicas. Isabel II y la Revolución de septiembre de 1868" [en línea], en Tebeosfera, 12 (2014). [Consulta: 2 de febrero de 2017]. Disponible en: www.tebeosfera.com/documentos/la_prensa_satiricografica_en_las_otras_abdicaciones_borbonicas._isabel_ii_y_la_revolucion_de_septiembre de 1868. html

Ortega, Marie-Linda: "Le (dis)continu á l'oeuvre dans les blagues illustrées du XIXe: éclats du rire", en Carole Fillière y Laurie Anne Laget (coords.): Les relations esthétiques entre ironie et humour en Espagne, XIXe-XXe siècles, Madrid, Casa de Velázquez, 2011, pp. 39-50. 
— "El arte de Ortego en la prensa", en Marie-Linda Ortega (ed.): Ojos que ven, ojos que leen. Textos e imágenes en la España isabelina, Madrid, Visor, 2004, pp. 201-216.

Seoane, María Cruz: Historia del periodismo en España. 2. El siglo XIX, Madrid, Alianza, 1989.

Simón Palmer, María del Carmen: "La publicidad y la imagen en Madrid (1840-1874)", en Marie-Linda Ortega (ed.): Ojos que ven, ojos que leen. Textos e imágenes en la España isabelina, Madrid, Visor, 2004, pp. 11-38.

Valle-Inclán, Ramón María: Sonata de Invierno, Madrid, Espasa Calpe, 1981. (1ª ed. 1944).

VV. AA.: La caricature... et si c'était sérieux? Décryptrage de la violence satirique, París, Noveau Monde, 2015.

\section{Prensa}

Matoses, Manuel: “Conjunción”, en Gil Blas, 392 (6 de agosto de 1871), pp. 1 y 2.

Sojo, Eduardo: “Telégramas”, en El Noventa y Tres, 3 (5 de diciembre de 1870), p. 4.

— "Chispazos", en El Caos, 10 (5 de junio de 1870), p. 1.

— "Chispazos", en El Caos, 13 (26 de junio de 1870), p. 4.

- [Sin título], El Lio, 2 (14 de febrero de 1874), p. 1.

- [Sin título], Gil Blas, 114 (3 de noviembre de 1867), p. 4.

— "Cabos sueltos", en Gil Blas, 20 (12 de enero de 1868) p. 3.

- "Á lo que vengo", en La Carcajada, 1 (17 de enero de 1872), p. 1.

- "España”, en La Carcajada, 15 (6 de mayo de 1872) p. 4.

— "Advertencia", en La Correspondencia del Diablo, 2 (10 de abril de 1872), p. 1.

- Europa”, en La Correspondencia del Diablo, 9 (27 de octubre de 1872), pp. 1 y 2.

_ “Tardis piulasti”, en La Flaca, 37 (6 marzo 1870), pp. 2 y 3.

— “Advertencias", en Mundo Cómico, 139 (27 de junio de 1875), p. 8. 